\title{
Microbial communities associated with wet flue gas desulfurization systems
}

\author{
Bryan P. Brown ${ }^{1+}$, Shannon R. Brown ${ }^{2}$ and John M. Senko ${ }^{1,3 *}$ \\ ${ }^{1}$ Department of Biology, The University of Akron, Akron, OH, USA \\ 2 Babcock \& Wilcox Power Generation Group, Inc. Barberton, OH, USA \\ ${ }^{3}$ Department of Geology and Environmental Science, The University of Akron, Akron, OH, USA
}

\section{Edited by:}

Jesse Dillon, California State

University, USA

Reviewed by:

John R. Spear, Colorado School of

Mines, USA

Tim Magnuson, Idaho State

University, USA

*Correspondence:

John M. Senko, Department of

Geology and Environmental

Science, The University of Akron,

Akron, OH 44325-4101, USA.

e-mail: senko@uakron.edu

${ }^{\dagger}$ Present address:

CIEMAS/Fitzgerald Building, Duke

University, 101 Science Drive,

Durham, NC 27708, USA.
Flue gas desulfurization (FGD) systems are employed to remove $\mathrm{SO}_{x}$ gasses that are produced by the combustion of coal for electric power generation, and consequently limit acid rain associated with these activities. Wet FGDs represent a physicochemically extreme environment due to the high operating temperatures and total dissolved solids (TDS) of fluids in the interior of the FGD units. Despite the potential importance of microbial activities in the performance and operation of FGD systems, the microbial communities associated with them have not been evaluated. Microbial communities associated with distinct process points of FGD systems at several coal-fired electricity generation facilities were evaluated using culture-dependent and -independent approaches. Due to the high solute concentrations and temperatures in the FGD absorber units, culturable halothermophilic/tolerant bacteria were more abundant in samples collected from within the absorber units than in samples collected from the makeup waters that are used to replenish fluids inside the absorber units. Evaluation of bacterial 16S rRNA genes recovered from scale deposits on the walls of absorber units revealed that the microbial communities associated with these deposits are primarily composed of thermophilic bacterial lineages. These findings suggest that unique microbial communities develop in FGD systems in response to physicochemical characteristics of the different process points within the systems. The activities of the thermophilic microbial communities that develop within scale deposits could play a role in the corrosion of steel structures in FGD systems.

Keywords: flue gas desulfurization, thermophiles, microbially influenced corrosion

\section{INTRODUCTION}

Sulfur-oxide gasses (mostly $\mathrm{SO}_{2}$ ) that are released during the combustion of fossil fuels (most notably from coal-fired electricity generation) are known to cause acid rain (Cullis and Hirschler, 1980). To limit acid rain, flue gas desulfurization (FGD) systems (often referred to as "scrubbers") are routinely used to remove $\mathrm{SO}_{2}$ from the exhaust of coal-fired electric power facilities (Pandy et al., 2005). For limestone-based wet FGD, coal combustion exhaust (flue gas) is diverted into absorber units and passed under a spray of crushed limestone-water slurry (Figure 1), whereupon, flue gas-associated $\mathrm{SO}_{2}$ dissolves in the water as sulfite (Equation 1).

$$
\mathrm{SO}_{2}+\mathrm{H}_{2} \mathrm{O} \rightarrow \mathrm{SO}_{3}^{2-}+2 \mathrm{H}^{+}
$$

Slurries are initially prepared by mixing the crushed limestone with water sourced from a large body of freshwater (e.g., a lake or river). Slurry spray is collected at the bottom of the absorber unit, and sulfite subsequently precipitates with $\mathrm{Ca}^{2+}$ (Equation 2) produced from dissolution of $\mathrm{CaCO}_{3}$ in the limestone.

$$
\mathrm{Ca}^{2+}+\mathrm{SO}_{3}^{2-} \rightarrow \mathrm{CaSO}_{3}
$$

The $\mathrm{O}_{2}$ in forced air that is injected into the absorber unit (Figure 1) facilitates the oxidation of the sulfite moiety of $\mathrm{CaSO}_{3}$ to sulfate, forming gypsum (Equation 3).

$$
2 \mathrm{CaSO}_{3}+\mathrm{O}_{2}+4 \mathrm{H}_{2} \mathrm{O} \rightarrow 2 \mathrm{CaSO}_{4} \cdot 2 \mathrm{H}_{2} \mathrm{O}_{\text {gypsum }}
$$

The slurry at the bottom of the absorber unit may be recirculated through the spray nozzles or subjected to dewatering (to recover gypsum) and water purification (to remove dissolved solids) (Figure 1; Rajendran et al., 1999).

The treated slurry water may be released into a water body or held onsite (as "reuse water"), mixed with fresh limestone, and circulated back into the absorber unit (Figure 1). Slurry water that is lost due to evaporation and during gypsum recovery may be replaced using fresh limestone mixed with makeup water (water obtained from a nearby water body and held in onsite tanks) or reuse water (Figure 1). The interior of FGD absorber units may be considered a physicochemically extreme environment, since (1) heat from the flue gas maintains temperatures of $50-80^{\circ} \mathrm{C}$, and (2) absorber unit fluids may contain total dissolved solids (TDS) concentrations of nearly $40 \mathrm{~g} / \mathrm{l}$, including approximately $0.5 \mathrm{M} \mathrm{Cl}^{-}$and similarly high $\mathrm{SO}_{4}^{2-}$ concentrations (Kiil et al., 1998; Nygaard et al., 2004; Kitto and Stultz, 2005; Cooper 


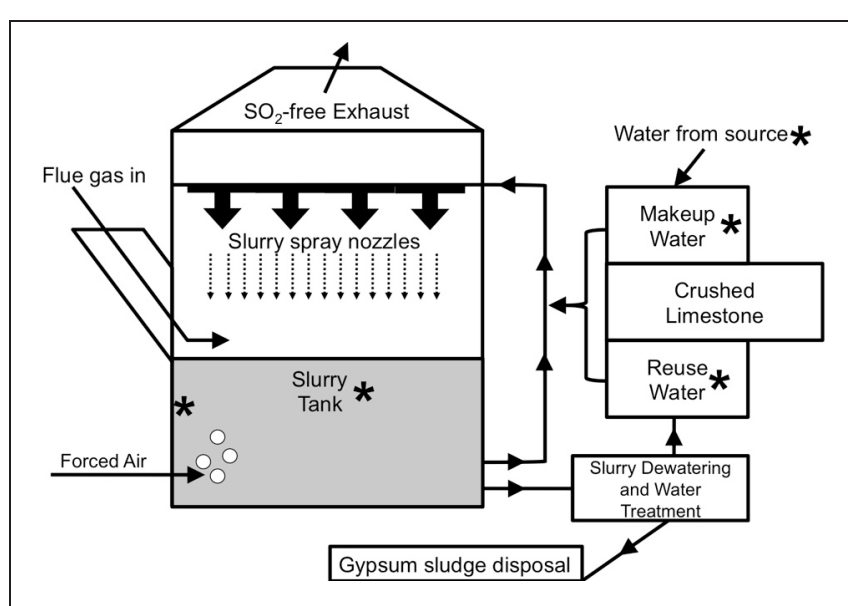

FIGURE 1 | Schematic depiction of the operation of a limestone-based wet FGD system [adapted from Kiil et al. (1998)]. Asterisks are used to point out locations where samples were obtained from the FGD systems evaluated in this study.

and Ruocco, 2010; Van Ginkel et al., 2011). High TDS in absorber unit fluids are a result of chemical inputs from coal combustion products, limestone, and source water, as well as the subsequent concentration of dissolved species resulting from evaporation from the absorber unit (Kitto and Stultz, 2005).

Given the abilities of microorganisms to modulate the oxidation states of sulfur species, such activities may be exploited to enhance the performance of FGD systems. For instance, sulfate reducing, $\mathrm{Fe}(\mathrm{II})$ - and sulfide-oxidizing, and phototrophic bacterial activities may be exploited for removal of $\mathrm{SO}_{2}$ (Dasu et al., 1993; Huber and Stetter, 1998; Pandy et al., 2005; Parshina et al., 2005, 2010), though these activities have not been considered in the context of existing FGD systems. Given the high operating temperatures associated with FGD units, thermophilic microorganisms would be best suited for biotechnological approaches to FGD and $\mathrm{SO}_{2}$ removal (Huber and Stetter, 1998). Furthermore, the high TDS of slurry fluids will favor the activities of organisms that are capable of tolerating high osmotic strength fluids. Due to the required oxic conditions, relatively high operating temperatures, high $\mathrm{Cl}^{-}$, and $\mathrm{SO}_{4}^{2-}$ concentration, and potentially low $\mathrm{pH}$ of FGD absorber slurries, they represent an extremely corrosive environment (Mansfield and Jeanjaquet, 1987; Hibner and Ross, 1988; Bordziłowski and Darowicki, 1998; Rajendran et al., 1999; Kim et al., 2010). As such, degradation of the steel walls and other structures is a significant concern for FGD operators. More recently, microbially influenced corrosion (MIC) has been proposed to be responsible for the deterioration of the steel walls and other structures associated with absorber units (Moskal, 2011).

Despite the potentially beneficial (i.e., enhanced $\mathrm{SO}_{2}$ removal) and detrimental (i.e., MIC) impacts of microbial activities in FGD systems, we are not aware of any studies of the microbiology of operating FGD units. In this study we evaluated the microbial communities associated with the fluids from the wet FGD systems of five coal-fired electric power generation facilities. Samples were collected from various process points, including source water, makeup, and reuse waters, and from slurries inside FGD absorber units (Figure 1). We hypothesized that the physicochemical differences among these various "process points" of the FGD systems would give rise to distinct microbial communities within the broader FGD system. These studies also included the characterization of microbial communities associated with scale deposits recovered from the steel walls of a severely corroded absorber unit and a unit that is not currently exhibiting signs of corrosion.

\section{MATERIALS AND METHODS FACILITIES, FGD UNITS, AND SAMPLING METHODS}

Samples were collected from wet FGD systems of five coal-fired electric power facilities. Samples with their corresponding sample designations are included in Tables 1, 2. Three distinct process points within the FGD systems were sampled, including absorber slurries of Facilities A-E and makeup waters of Facilities A-D. Samples were collected from absorber slurries of two different FGD units at Facilities A-C. Scale deposits on the walls of absorbers at Facilities A and B were collected when these units were drained for periodic maintenance. Slurry samples from Unit 2 of Facilities A and B were collected approximately 1 month after maintenance activities and subsequent startup. Additionally, a sample was collected near the water intake for Facility A from a freshwater body that provides the source water for Facilities A and B. Source waters for Facilities C, D, and E were not sampled for this study. Raw makeup/reuse water, absorber slurry, and source water were collected by filling sterile bottles with operating process fluid by holding them under a flowing stream at the unit sampling port. Hard, mineralized scale deposits from the walls of absorber units that were likely derived from slurry solids were collected by scraping and transferring the deposits to sterile centrifuge tubes with a sterile plastic spatula. All samples were refrigerated and shipped via overnight courier to The University of Akron, where they were processed further. Subsamples for culture-dependent microbial enumerations and evaluation of solid-phase chemistry were stored at $4^{\circ} \mathrm{C}$ (for no more than 2 week) before further processing (described below). Subsamples for analysis of aqueous chemistry were immediately filter sterilized $(0.2 \mu \mathrm{m}$ pore size) upon receipt in the laboratory and stored at $4^{\circ} \mathrm{C}$ prior to analysis. Subsamples for nucleic acid-based microbial community analysis were transferred to a $-80^{\circ} \mathrm{C}$ freezer before further processing (described below).

\section{ANALYTICAL METHODS}

The $\mathrm{pH}$ of source water, makeup waters, and absorber slurries was measured immediately upon receipt in the laboratory. Dissolved anions $\left(\mathrm{Cl}^{-}, \mathrm{NO}_{3}^{-}\right.$, and $\left.\mathrm{SO}_{4}^{2-}\right)$ in filtered source water, makeup waters, and absorber slurries were quantified by ion chromatography using a Dionex DX-120 ion chromatography system fitted with an AS4 column and conductivity detector (Sunnyvale, CA). Carbonate alkalinity was determined by titration of the fluids with $\mathrm{H}_{2} \mathrm{SO}_{4}$ to a $\mathrm{pH}$ of 4.5 (Greenberg et al., 1981). Filtered subsamples intended for analysis of dissolved cations were preserved in $0.5 \mathrm{M} \mathrm{HCl}$, and subsequently analyzed for $\mathrm{Fe}^{2+}$ by ferrozine assay (Stookey, 1970) and dissolved Ca and Mn by atomic absorption spectrometry (AA), using a Perkin Elmer Analyst 700 (Waltham, MA). Solid-phases that were suspended in slurries or associated with scale deposits were digested 
Table 1 | Aqueous chemical composition of source, makeup, reuse, and slurry fluids.

\begin{tabular}{|c|c|c|c|c|c|c|c|c|c|c|}
\hline Sample & $\begin{array}{l}\text { Sample } \\
\text { designation }\end{array}$ & $\mathrm{pH}$ & $\begin{array}{l}\mathrm{Cl}^{-} \\
(\mathrm{mM})\end{array}$ & $\begin{array}{l}\mathrm{NO}_{3}^{-} \\
(\mathrm{mM})\end{array}$ & $\begin{array}{l}\mathrm{SO}_{4}^{2-} \\
(\mathrm{mM})\end{array}$ & $\begin{array}{l}\mathrm{Fe}(\mathrm{II}) \\
(\mu \mathrm{M})\end{array}$ & $\begin{array}{l}\mathrm{Mn} \\
(\mathrm{mM})\end{array}$ & $\begin{array}{l}\mathrm{Ca} \\
(\mathrm{mM})\end{array}$ & $\begin{array}{l}\text { DOC } \\
(\mathrm{mg} / \mathrm{l})\end{array}$ & $\begin{array}{l}\text { Carbonate Alkalinity } \\
\text { (meq/l) }\end{array}$ \\
\hline Facility A Unit 1 absorber slurry & A-U1 $1_{\text {slurry }}$ & 5.8 & 413 & 45 & 563 & $n / d$ & 0.96 & 6.0 & 118 & 4.1 \\
\hline Facility A Unit 1 makeup water & A-U1 makeup & 6.5 & 0.88 & $n / d$ & 0.25 & $n / d$ & 0.55 & 6.0 & 9.5 & $\mathrm{n} / \mathrm{a}$ \\
\hline Facility A source water & $A_{\text {source }}$ & 6.5 & 1.13 & $n / d$ & 0.38 & $n / d$ & 0.64 & 3.2 & 4.4 & $\mathrm{n} / \mathrm{a}$ \\
\hline Facility B Unit 1 reuse water & $\mathrm{B}-\mathrm{U} 1_{\text {reuse }}$ & 6.6 & 0.75 & $n / d$ & 0.63 & $n / d$ & 0.04 & 1.6 & 13 & $\mathrm{n} / \mathrm{a}$ \\
\hline Facility C Unit 1 absorber slurry & $\mathrm{C}-\mathrm{U} 1_{\text {slurry }}$ & 6.6 & 335 & $n / d$ & 760 & 30 & 1.83 & 9.8 & 179 & 10.4 \\
\hline Facility C Unit 2 absorber slurry & $\mathrm{C}-U 2_{\text {slurry }}$ & 6.2 & 754 & $n / d$ & 1623 & 500 & 0.97 & 4.7 & 191 & 13.5 \\
\hline Facility C Unit 1 makeup water & $\mathrm{C}-\mathrm{U} 1_{\text {makeup }}$ & 6.5 & $n / d$ & $n / d$ & $n / d$ & 49 & $n / d$ & 0.6 & 7.9 & $\mathrm{n} / \mathrm{a}$ \\
\hline Facility C Unit 2 makeup water & $\mathrm{C}-\mathrm{U} 2_{\text {makeup }}$ & 7.3 & $n / d$ & $n / d$ & $n / d$ & 55 & $n / d$ & 0.6 & 9.3 & $\mathrm{n} / \mathrm{a}$ \\
\hline
\end{tabular}

n/a, not analyzed; $n / d$, not detected.

Table 2 | Solid-phase chemistry of suspended solids in slurry and wall scales from FGD absorber units.

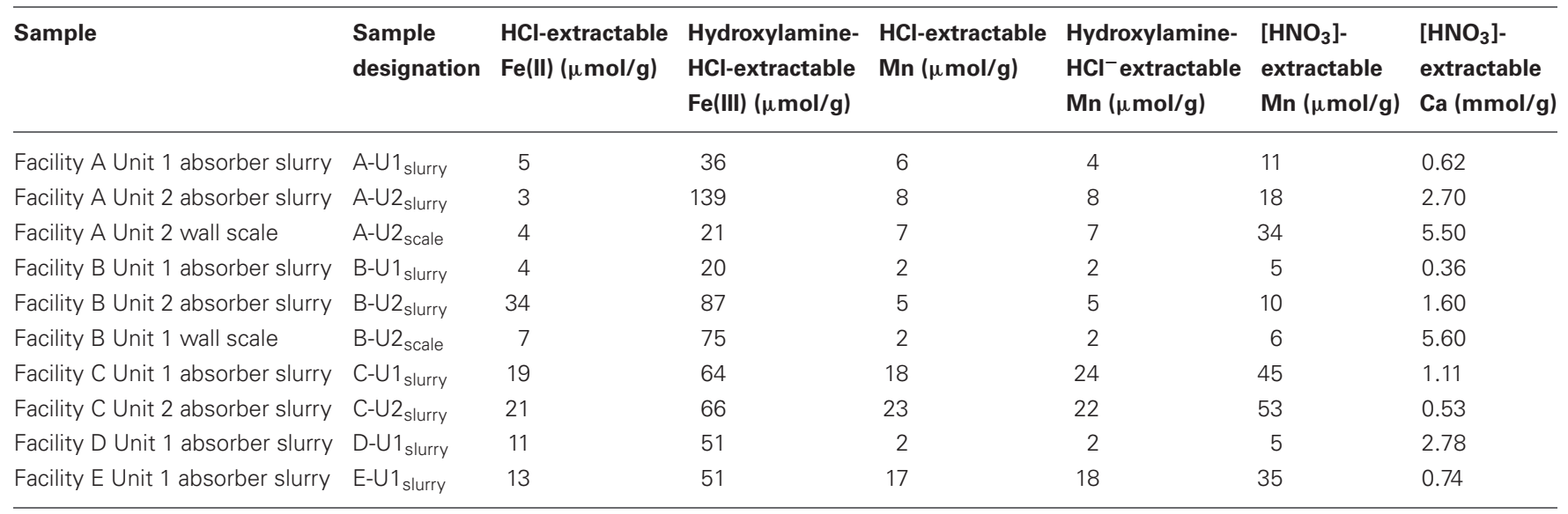

using $0.5 \mathrm{M} \mathrm{HCl}$ [operationally defined as solid-associated $\mathrm{Fe}(\mathrm{II})$ Lovley and Phillips (1987) and Mn(II/III) Sutter et al. (1974)], $0.25 \mathrm{M}$ hydroxylamine- $\mathrm{HCl}$ in $0.25 \mathrm{M} \mathrm{HCl}$ [operationally defined as poorly crystalline $\mathrm{Fe}(\mathrm{III})$ Lovley and Phillips (1987) and $\mathrm{Mn}\left(\mathrm{III} / \mathrm{IV}\right.$ ) Sutter et al. (1974)], and concentrated $\mathrm{HNO}_{3}$ (operationally defined as total $\mathrm{Mn}$ and $\mathrm{Ca}$ ), and remaining solids were removed from suspensions by centrifugation. Extracted $\mathrm{Fe}(\mathrm{II})$ was quantified by ferrozine assay (Stookey, 1970), and extracted $\mathrm{Mn}$ and Ca were quantified by AA, as described above. Solid contents of absorber slurries were determined gravimetrically after drying $5 \mathrm{ml}$ of slurry.

\section{CULTURE-DEPENDENT MICROBIAL ENUMERATIONS}

Total aerobic organoheterotrophic microorganisms were enumerated using culture-dependent approaches with modified liquid versions of $\mathrm{K}$ and Lept media described by Templeton et al. (2005) in a most probable number (MPN) format (Colwell, 1979). Modified Lept medium was buffered with piperazine-N, $\mathrm{N}^{\prime}$-bis(2ethanesulfonic acid) (PIPES; $\mathrm{pH}$ 6.5) and contained $\mathrm{Na}_{2} \mathrm{SO}_{4}$
(250 mM), glucose (5 mM), $\mathrm{MgSO}_{4}(0.8 \mathrm{mM}), \mathrm{CaCl}_{2}(0.8 \mathrm{mM})$, yeast extract $(0.5 \mathrm{~g} / \mathrm{l})$, casamino acids $(0.5 \mathrm{~g} / \mathrm{l})$, and trace metals described by Tanner (1997). K medium was buffered with PIPES ( $\mathrm{pH}$ 6.5) and contained $\mathrm{Na}_{2} \mathrm{SO}_{4}(250 \mathrm{mM})$, peptone $(2 \mathrm{~g} / \mathrm{l})$, and yeast extract $(0.5 \mathrm{~g} / \mathrm{l})$. MPN cultures were incubated aerobically at $50^{\circ} \mathrm{C}$. MPN dilution series were scored for heterotrophic growth based on the appearance of turbidity in the medium.

\section{NUCLEIC ACID-BASED MICROBIAL COMMUNITY CHARACTERIZATION}

In preparation for extraction of genomic DNA, solids that were suspended in slurry samples were concentrated by centrifugation and the supernatant was removed. Since the slurry solids retained a large volume of water, the remaining solids were lyophilized to maximize the amount of solids from which DNA could be extracted. DNA was subsequently extracted from slurry solid-associated microorganisms $(\sim 0.5 \mathrm{~g}$ of slurry solids) using MoBio PowerBiofilm DNA isolation kits (MoBio Laboratories, Inc., Carlsbad, CA). Planktonic microorganisms associated with makeup waters or source water was immobilized 
on hydrophilic polyethersulfone membranes $(0.2 \mu \mathrm{m}$ pore size $)$ by vacuum filtration. Approximately 0.51 of water was filtered, and approximately half of the $17 \mathrm{~cm}^{2}$ filter was subjected to genomic DNA extraction using MoBio PowerBiofilm DNA isolation kits. DNA was quantified using a Nanodrop spectrophotometer (Thermo Scientific Inc., Waltham, MA) and yields ranged from 310 to $1800 \mathrm{ng}$ DNA/sample. Partial sequences of bacterial 16S rRNA genes were obtained using tag-encoded FLX amplicon pyrosequencing at Research and Testing Laboratories, Inc. (Lubbock, TX) as described by Dowd et al. (2008) using Gray28f (5'-TTTGATCNTGGCTCAG-3') and Gray519r (5'GTNTTACNGCGGCKGCTG-3') primers. Initial generation of the sequencing library utilized a one-step PCR with a total of 30 cycles, a mixture of HotStart and HotStar high fidelity taq polymerases, and amplicons originating and extending from the $28 \mathrm{~F}$ position. Tag-encoded FLX amplicon pyrosequencing was conducted using a Roche 454 FLX pyrosequencer with Titanium reagents (Roche 454 Life Sciences, Branford, CT). Following sequencing, all failed sequence reads, low quality sequence ends, and tags and primers were removed. Non-bacterial ribosomal sequences and chimeras were removed using B2C2 (Gontcharova et al., 2010). Short reads (<150 bp), sequences with ambiguous base calls, and sequences with homopolymers $>6$ bp were removed from the library. Nucleotide sequence libraries obtained in this work have been submitted to the Sequence Read Archive (SRA) under run accession num-

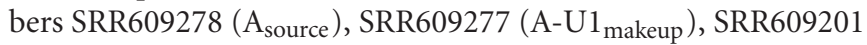
(A-U1 $\left.1_{\text {slurry }}\right)$, SRR609275 (A-U2 $\left.2_{\text {slurry }}\right)$, SRR609276 (A-U2 scale $_{\text {e), }}$ SRR609281 (B-U1 $\left.1_{\text {reuse }}\right)$, SRR609279 (B-U1 $1_{\text {slurry }}$ ), SRR609280 (B-U2 slurry), SRR609282 (B-U2 scale $),$ SRR609285 (C-U1 makeup), SRR609283 (C-U1 $1_{\text {slurry }}$ ), SRR609286 (C-U2 makeup), SRR609284 (C-U2 $2_{\text {slurry }}$ ), SRR609288 (D-U1 $\left.1_{\text {makeup }}\right)$, SRR609287 (D-U1 $1_{\text {slurry }}$ ), and SRR609292 (E-U1 $\left.1_{\text {slurry }}\right)$.

To evaluate the diversity of the various FGD-associated systems, standard rarefaction curves (based on $97 \%$ sequence identity) were produced for each unique FGD environment (i.e., absorber scale, absorber slurry, makeup water, and source water) using the Ribosomal Database Project's (RDPs)-II Pyrosequencing Pipeline (Cole et al., 2009). RDPII Pyrosequencing Pipeline was also used to calculate Shannon and Chaol diversity indices at a cutoff of $97 \%$ sequence identity. Sequences were processed and analyzed further using the MacQIIME (http://www.wernerlab.org/software/macqiime) version of the QIIME software package using default parameters (Caporaso et al., 2010b). Sequences were separated into operational taxonomic units based on $97 \%$ sequence identity, and representative OTUs were picked using scripts in the QIIME environment (Edgar, 2010). Taxonomic assignments were made to OTUs using the RDP II's classifier function (Wang et al., 2007) in the QIIME environment. OTU sequences were aligned using the PyNAST algorithm (Caporaso et al., 2010a) against the Greengenes core set (DeSantis et al., 2006), filtered to remove gaps, and a phylogenetic tree was constructed using QIIME. In preparation for beta-diversity analyses, the OTU table from each sample was iteratively rarefied to 1009 sequences using Jack-knife sampling in QIIME. A distance matrix was produced using the weighted UniFrac beta-diversity metric (Lozupone and Knight,
2005), and microbial communities associated with the samples were compared visually using Principal Coordinate Analysis (PCoA) (Lozupone and Knight, 2005).

\section{RESULTS}

\section{CHEMICAL CHARACTERISTICS OF FGD FLUIDS AND SOLIDS}

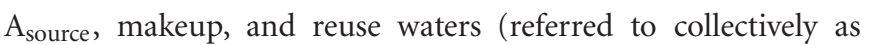
"fresh" waters) contained dissolved chemical species at similar concentrations (Table 1). B-U1 $1_{\text {reuse }}$ contained the highest concentrations of $\mathrm{Cl}^{-}$and $\mathrm{SO}_{4}^{2-}$ (Table 1), which is likely attributable to the incomplete removal of these dissolved species by slurry water treatment. Slurry fluids contained higher concentrations of dissolved $\mathrm{Ca}$ than source waters and carbonate alkalinities ranging from 3.5 to $13.5 \mathrm{meq} / \mathrm{l}$ due to limestone dissolution (Table 1 ). $\mathrm{Cl}^{-}, \mathrm{NO}_{3}^{-}, \mathrm{SO}_{4}^{2-}$ concentrations in slurry fluids ranged from 73 to $754 \mathrm{mM}$, undetectable- $45 \mathrm{mM}$, and $15-1623 \mathrm{mM}$, respectively (Table 1). WEB-PHREEQ-based geochemical modeling (SainiEidukat and Yahin, 1999) using the values contained in Table 1 suggested that all slurry fluids except $\mathrm{B}-\mathrm{U} 1_{\text {slurry }}$ were supersaturated with respect to gypsum $\left(\mathrm{CaSO}_{4} \cdot 2 \mathrm{H}_{2} \mathrm{O}\right)$, and all slurry fluids except $\mathrm{A}-\mathrm{U} 1_{\text {slurry }}, \mathrm{B}-\mathrm{U} 1_{\text {slurry }}$, and $\mathrm{E}-\mathrm{U} 1_{\text {slurry }}$ were supersaturated with respect to anhydrite $\left(\mathrm{CaSO}_{4}\right)$. Slurry fluids were enriched in $\mathrm{Mn}$ in comparison to source, makeup, or reuse waters, though dissolved $\mathrm{Fe}$ (II) concentrations were generally low due to the abundance of oxygen in the fluids (Table 1). Absorber slurries contained considerably higher levels of DOC than "fresh" waters (Table 1), which is likely attributable to non- or partially combusted coal and ash that were not removed by the electrostatic precipitator and entered the absorber unit with the flue gas. $\mathrm{HCl}$-extractable $\mathrm{Fe}(\mathrm{II})$ and $\mathrm{Mn}$ (II/III) contents of solids ranged from 20 to $34 \mu \mathrm{mol} / \mathrm{g}$ and 1.7 to $23 \mu \mathrm{mol} / \mathrm{g}$, respectively (Table 2). Hydroxylamine-HCl-extractable Fe(III) and $\mathrm{Mn}$ contents of solids ranged from 20 to $139 \mu \mathrm{mol} / \mathrm{g}$ and 1.7 to $24.5 \mu \mathrm{mol} / \mathrm{g}$, respectively (Table 2). Total $\mathrm{Mn}$ and Ca contents ranged from 4.7 to $52.8 \mu \mathrm{mol} / \mathrm{g}$ and 0.36 to $5.6 \mathrm{mmol} / \mathrm{g}$, respectively (Table 2). The variability in concentrations of both dissolved and solid-phase chemical constituents is likely a reflection of variability in raw materials (e.g., water, coal, and limestone) used in the facilities. Electric power generation stations use water from nearby water supplies and frequently utilize locally sourced limestone. Differences in chemical composition of raw materials will in turn influence the chemical composition of absorber fluids. Facilities A and B are $\sim 80 \mathrm{~km}$ apart, are owned by the same utility company, and use coal and limestone types, and source waters from the same large freshwater body. Facilities C, D, and E are each located more than $300 \mathrm{~km}$ apart, and use different source waters and limestone types.

\section{CULTURE-DEPENDENT MICROBIAL ENUMERATIONS}

The chemical conditions in the absorber unit slurries represent an organic carbon-rich and osmotically challenging environment that is dramatically different from that of the "fresh" waters. Microorganisms are generally classified as halophilic/tolerant based on their ability to grow at high $\mathrm{NaCl}$ concentrations (Trüper and Galinski, 1986; Ventosa et al., 1998), and while $\mathrm{Cl}^{-}$concentrations in FGD slurry fluids were quite high, $\mathrm{SO}_{4}^{2-}$ was generally the dominant anionic constituent (Table 1). As such, 
we enumerated organotrophic microorganisms in all points of the FGD systems using two types of media that were incubated at $50^{\circ} \mathrm{C}$ and contained $250 \mathrm{mM} \mathrm{Na}_{2} \mathrm{SO}_{4}$ to specifically target organisms that were able to grow under the osmotic stress imposed by the high sulfate concentrations of the FGD slurry fluids. The physicochemical differences between "fresh" waters and the absorber slurries were reflected in the abundances of organotrophic bacteria detected. When cultured on modified $\mathrm{K}$ and Lept media, relatively few halothermophilic/tolerant microorganisms were detected in "fresh" waters in comparison to absorber slurries (Table 3), suggesting that the high temperature and solute concentrations of the absorber units enrich for halothermophilic/tolerant microorganisms. It is notable that of the "fresh" waters, $\mathrm{B}-\mathrm{U} 1_{\text {reuse }}$ contained the highest number of halothermophilic/tolerant organisms (Table 3 ). Since $\mathrm{B}-\mathrm{U} 1_{\text {reuse }}$ water is recycled absorber fluid, halothermophilic/tolerant microorganisms were retained in these fluids. While A-U2 $2_{\text {scale }}$ was enriched in halothermophilic/tolerant microorganisms in comparison to A$\mathrm{U} 1_{\text {slurry }}$ and A-U2 $2_{\text {slurry }}, \mathrm{B}-\mathrm{U} 2_{\text {scale }}$ contained comparable numbers of halothermophilic/tolerant organoheterotrophs to B-U1 $1_{\text {slurry }}$ and B-U2 $2_{\text {slurry }}$ (Table 3), which may also be attributable to the recirculation of halothermophilic/tolerant organisms in Facility $\mathrm{B}$ reuse water (Figure 1).

\section{NUCLEIC ACID-BASED COMMUNITY PROFILING}

The numbers of sequences analyzed, numbers of OTUs, and diversity indices associated with bacterial communities in FGD systems are shown in Table 3. A total of 1,05,769 sequences were analyzed from 16 samples, and average read length was $360 \mathrm{bp}$. Rarefaction analysis was used to compare the richness of bacterial communities associated with various process points of the FGD systems (Figure 2). While absorber slurries, wall scales, and B$\mathrm{U} 1_{\text {reuse }}$ were sampled to saturation, source, and makeup waters were not (Figure 2). The highest numbers of OTUs were recovered in the four makeup waters sampled (Table 3), and while only 1009 sequences were obtained from $\mathrm{A}_{\text {source}}$, this sample exhibited a similar rarefaction pattern to the makeup waters (Figure 2). Non-parametric indicators of diversity showed similar trends, with the highest Chaol and Shannon richness estimates observed in the makeup waters (Table 3). These results suggest that more complex microbial communities are associated with the makeup and source waters than the more physicochemically extreme absorber units (slurry and scale samples), but B-U $1_{\text {reuse }}$ is a notable exception to this conclusion. Even though $\mathrm{B}-\mathrm{U} 1_{\text {reuse }}$ had a similar chemical composition to source and makeup waters, bacterial communities associated with this system exhibited low Chaol and Shannon diversity indices in a fashion similar to the slurries and scales (Table 3).

All FGD-associated microbial communities were compared using PCoA with the weighted UniFrac metric, which allows the simultaneous comparison of microbial communities present in several environments by evaluating the common evolutionary history of organisms present in those systems (Lozupone and Knight, 2005). Comparison of FGD-associated microbial communities visualized by plotting PC1 vs. PC2 revealed distinct clustering of "fresh" waters, slurries, and scales (Figure 3A). This clustering pattern may be attributable to the physicochemical conditions to which the microbial communities were exposed. The "fresh" waters were exposed to ambient air temperatures and contained low concentrations of dissolved solutes (Table 1). Slurry-associated microbial communities were exposed to higher concentrations of dissolved solutes (Table 1), and variably high

Table 3 | Microbial abundances and diversity estimates from FGD systems.

\begin{tabular}{|c|c|c|c|c|c|c|c|}
\hline \multirow[t]{3}{*}{ Sample } & \multicolumn{2}{|c|}{ Culturable organotrophs (MPN*) } & \multirow{3}{*}{$\begin{array}{l}\text { No. of } \\
\text { sequences }\end{array}$} & \multirow{3}{*}{$\begin{array}{l}\text { OTU }_{0.03} \\
\text { OTUs (\%) }\end{array}$} & \multirow[t]{3}{*}{ Genus level-assignable } & \multicolumn{2}{|c|}{ Diversity indices } \\
\hline & Modified & Modified & & & & Shannon & Chao1 \\
\hline & Lept medium & K medium & & & & & \\
\hline A-U1 $1_{\text {slurry }}$ & $1.1 \times 10^{7}$ & $9.3 \times 10^{5}$ & 11,908 & 184 & 86 & 2.3 & 113 \\
\hline A-U $2_{\text {scale }}$ & $1.2 \times 10^{8}$ & $5.2 \times 10^{8}$ & 4954 & 236 & 22 & 3.09 & 205 \\
\hline A-U2 $2_{\text {slurry }}$ & $1.5 \times 10^{3}$ & $4.4 \times 10^{5}$ & 6009 & 191 & 59 & 2.7 & 132 \\
\hline A-U1 makeup & $3.5 \times 10^{2}$ & $3.5 \times 10^{2}$ & 9381 & 1865 & 41 & 5.9 & 1628 \\
\hline Asource & $n / d$ & $n / d$ & 1009 & 335 & 51 & 4.1 & 271 \\
\hline B-U1 $1_{\text {slurry }}$ & $2.1 \times 10^{6}$ & $2.4 \times 10^{7}$ & 5516 & 113 & 79 & 1.8 & 57 \\
\hline $\mathrm{B}-\cup 2_{\text {scale }}$ & $7.6 \times 10^{7}$ & $1.2 \times 10^{5}$ & 9271 & 292 & 20 & 2.46 & 213 \\
\hline B-U2 $2_{\text {slurry }}$ & $1.5 \times 10^{5}$ & $4.4 \times 10^{5}$ & 9634 & 284 & 79 & 3 & 200 \\
\hline B-U1 reuse & $2.4 \times 10^{3}$ & $2.4 \times 10^{3}$ & 6708 & 330 & 48 & 3.5 & 294 \\
\hline C-U1 $1_{\text {slurry }}$ & $4.3 \times 10^{5}$ & $9.3 \times 10^{5}$ & 8016 & 163 & 75 & 2.4 & 88 \\
\hline C-U2 ${ }_{\text {slurry }}$ & $7.5 \times 10^{2}$ & $9.3 \times 10^{2}$ & 4133 & 110 & 65 & 2.8 & 128 \\
\hline $\mathrm{C}-U 1$ makeup & $7.5 \times 10^{0}$ & $n / d$ & 8319 & 2260 & 57 & 6.3 & 1956 \\
\hline $\mathrm{C}-U 2$ makeup & $2.3 \times 10^{0}$ & $2.3 \times 10^{0}$ & 7219 & 1692 & 41 & 5.5 & 1506 \\
\hline D-U1 slurry & $2.3 \times 10^{1}$ & $2.1 \times 10^{3}$ & 5355 & 123 & 61 & 2.4 & 92 \\
\hline $\mathrm{D}-U 1_{\text {makeup }}$ & $\mathrm{n} / \mathrm{a}$ & $\mathrm{n} / \mathrm{a}$ & 3721 & 1047 & 41 & 5.6 & 870 \\
\hline E-U1 slurry & $2.1 \times 10^{6}$ & $1.1 \times 10^{7}$ & 5437 & 218 & 42 & 2.9 & 177 \\
\hline
\end{tabular}

*Values represent MPN/g of scale and MPN/m/ of water or slurry.

$n / a$, not analyzed; $n / d$, not detected. 


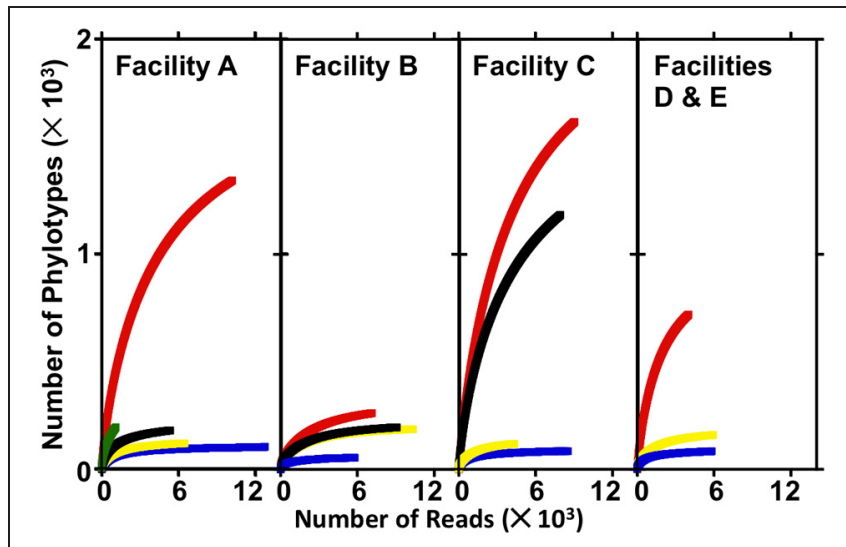

FIGURE 2 | Rarefaction curves produced from sequence libraries derived from source water, makeup waters, absorber slurries, and absorber scale deposits from electric power facilities A-E. In facility A, A source, $_{\text {a }} \mathrm{U} \cup 1_{\text {makeup }}, \mathrm{A}-\mathrm{U} 1_{\text {slurry }}, \mathrm{A}-\mathrm{U} 2_{\text {slurry }}$, and $\mathrm{A}-\mathrm{U} 2 \mathrm{~s}_{\text {cale }}$ are depicted by green, red, blue, yellow, and black lines, respectively. In facility $B$,

$\mathrm{B}-\mathrm{U} 1_{\text {makeup }}, \mathrm{B}-\mathrm{U} 1_{\text {slurry, }} \mathrm{B}-\mathrm{U} 2_{\text {slurry, }}$ and $\mathrm{B}-\mathrm{U} 2_{\text {scale }}$ are depicted by red, blue, yellow, and black lines, respectively. In facility C, C-U1 makeup, C-U2 makeup, $\mathrm{C}-\mathrm{U} 1_{\text {slurry, }}$ and $\mathrm{C}-\mathrm{U} 2_{\text {slurry }}$ are depicted by red, black, blue, and yellow lines, respectively. In facilities $\mathrm{D}$ and $\mathrm{E}, \mathrm{D}-\mathrm{U} 1_{\text {makeup }} \mathrm{D}-\mathrm{U} 1_{\text {slurry, }}$ and $\mathrm{E}-\mathrm{U} 1_{\text {slurry }}$ are depicted by red, blue, and yellow lines, respectively.

and low temperatures as the slurries were circulated through the FGD absorber units (Figure 1). Scale-associated microorganisms were exposed to continuously high temperatures and solute concentrations, since they were not circulated through the units. Notably, the B-U1 $1_{\text {reuse }}$ community did not cluster with the makeup or source waters in the PC1 vs. PC2 plot, even though it was exposed to physicochemical conditions similar to those of the other "fresh" waters (Table 1). As was observed with the culture-dependent enumerations and diversity metrics, this appears to be a reflection of the fact that $\mathrm{B}-\mathrm{U} 1_{\text {reuse }}$ is derived from treated absorber slurry. Indeed, the B-U1 reuse community appeared to cluster with the slurry-associated communities in the plot of PC1 vs. PC2 (Figure 3A). Clustering of communities based on FGD unit sampling location (and associated differences in physicochemical conditions) was not as pronounced in the PC2 vs. PC3 plot (Figure 3B). Separation of slurries and source/makeup waters was not observed by PC3 (Figure 3B). It is notable that PC3 allowed clustering of B-U $1_{\text {reuse }}$ with the source/makeup waters, which had similar physicochemical conditions (Figure 4B). The scale-associated communities remained well-separated from those of the slurries and source/makeup/reuse microbial communities, though they were separated by PC3 into different quadrants (Figure 3B).

These results suggest that the variability in physicochemical environment to which the microbial communities are exposed leads to the development of microbial communities with differing structures. For instance, exposure of slurry-associated microbial communities to higher solute concentrations and periodically higher temperature induces structural shifts from the "fresh" water microbial communities. However, since the slurry is continually replenished with makeup or reuse water, the slurries retain some characteristics of the "fresh" waters. Microbial communities
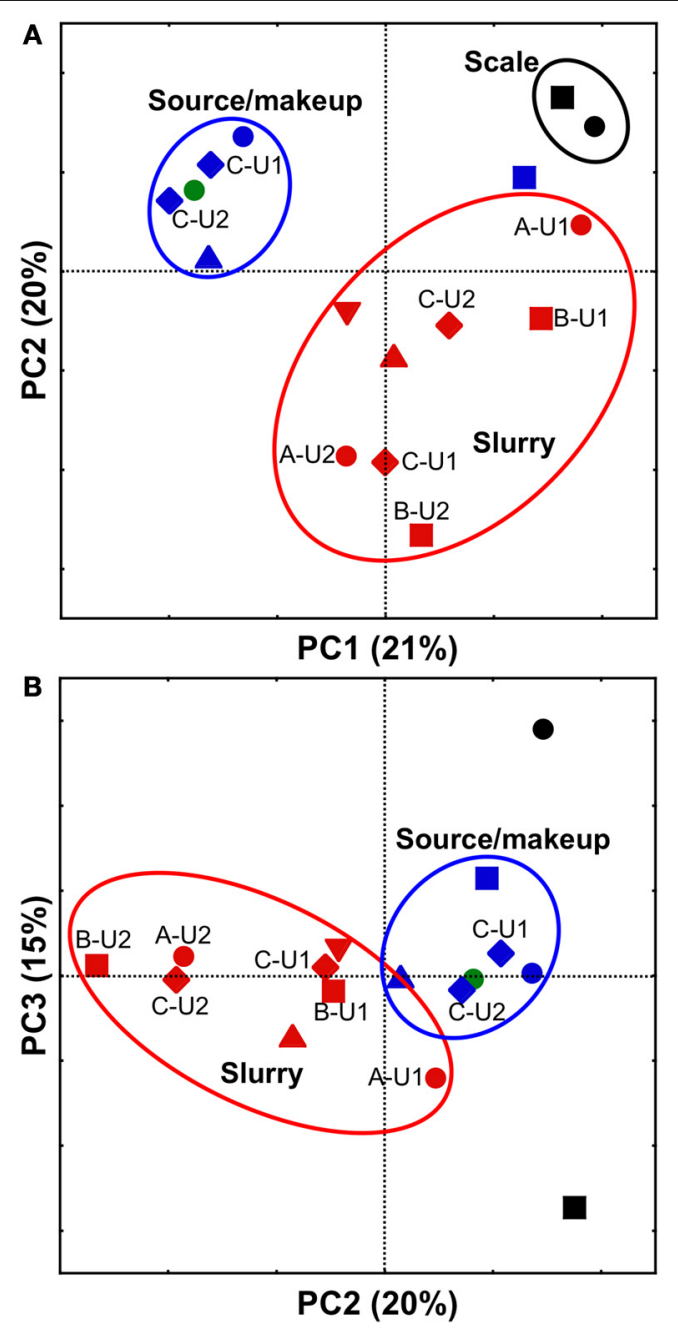

FIGURE 3 | PCoA analysis of scale- (black shapes), slurry- (red shapes), makeup water- (blue shapes), and source water- (green shape) associated bacterial communities using weighted UniFrac (Lozupone and Knight, 2005). Scatterplot of PC1 vs. PC2 is shown in (panel A), and scatterplot of PC2 vs. PC3 is shown in (panel B). Microbial communities observed in facilities (A, B, C, D, and E) are depicted using $\bullet, \mathbf{\square}, \boldsymbol{\bullet}, \mathbf{\Lambda}$, and $\mathbf{\nabla}$, respectively. In cases where more than one unit from the same facility was evaluated, unit numbers are shown next to their respective shape. Ovals are used to aid in visualization of "clustering" of microbial communities.

appear to develop in scales that are quite distinct from either the slurries or the makeup/source waters, since they are continuously exposed to higher temperatures and higher dissolved solute concentrations.

\section{EVALUATION OF TAXA IN "FRESH" WATERS AND ABSORBER SLURRIES}

Using the RDP classifier function (Wang et al., 2007) in the MacQIIME environment (Caporaso et al., 2010b), we were able to resolve $90-97 \%$, 96-99.4\%, and $96-97 \%$ of sequences to the phylum-level in "fresh" waters, slurries, and scales, respectively (Figures 4A,C,D). RDP classifier was able to assign as few as $41 \%$ of OTUs and as many as $86 \%$ of OTUs to the genus level in slurries and "fresh" 


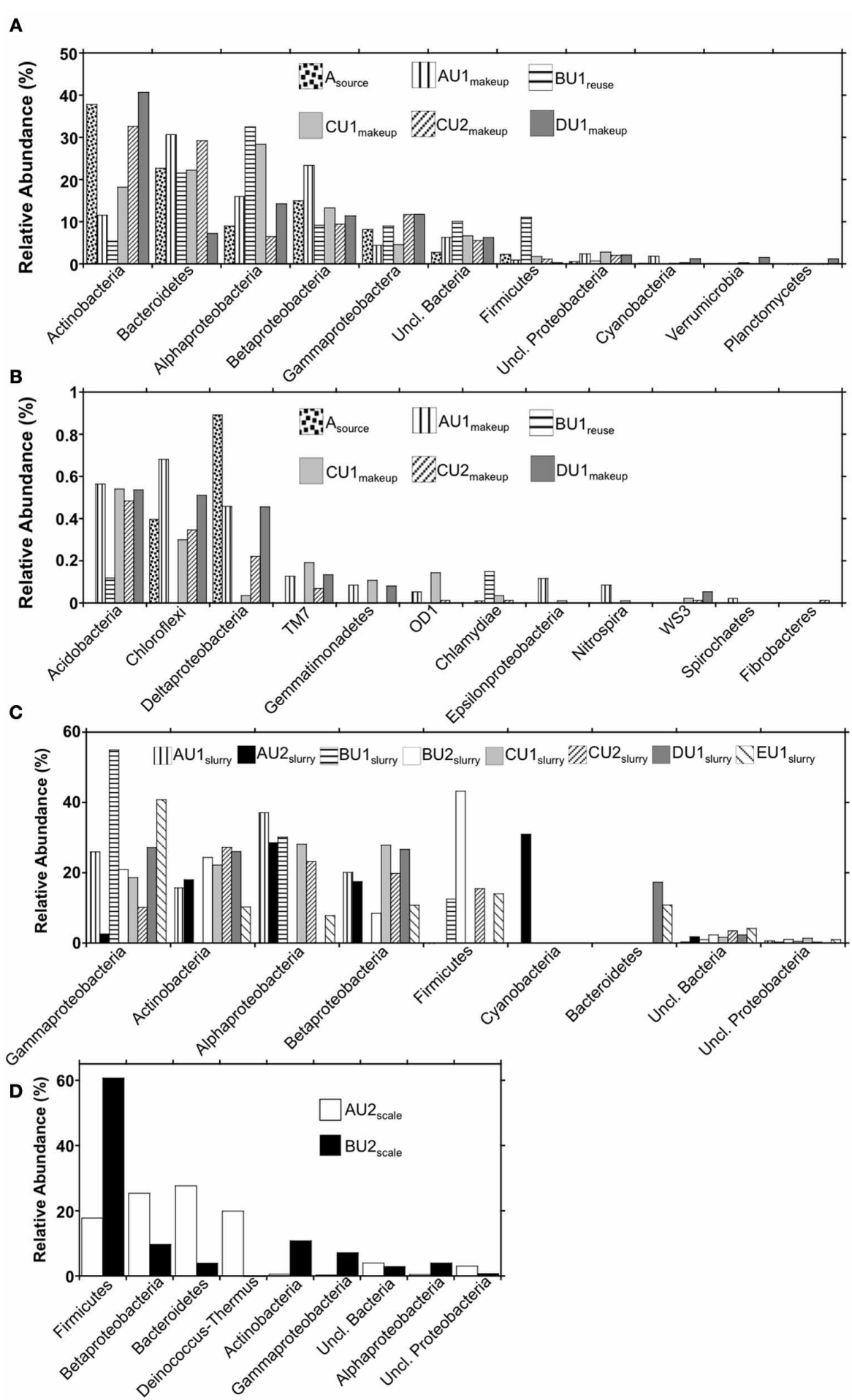

FIGURE 4 | Phylum-level (and class-level in the cases of the Proteobacteria) bacterial 16S rRNA gene OTU abundances in (panels A and B) makeup, reuse, and source waters, (panel C) absorber slurries, and (panel D) wall scales recovered from FGD units.

waters (Table 3). The majority of OTUs detected in the "fresh" waters were affiliated with Actinobacteria, Bacteroidetes, Alphaproteobacteria, Betaproteobacteria, Gammaproteobacteria, and Firmicutes (Figure 4A), though 15 other phyla were minimally abundant (i.e., $\leq 1 \%$ ) in at least one of the "fresh" water settings (Figure 4B). These patterns of phylum-level distribution are similar to other freshwater systems (Burkert et al., 2003; Allgaier and Grossart, 2006; Newton et al., 2007; Mueller-Spitz 
et al., 2009), including those that were characterized using similar sequencing effort (Clingenpeel et al., 2011). It is notable that the $\mathrm{B}-\mathrm{U} 1_{\text {reuse }}$ had fewer phyla represented (7) than in makeup waters (15-19), and this is reflected in the diversity indices determined for B-U $1_{\text {reuse }}$ (Table 3 ).

Microbial communities associated with slurries exhibited phylum-level profiles similar to those of the source and makeup waters, with abundant Actinobacteria-, Gammaproteobacteria-, Betaproteobacteria-, and Alphaproteobacteria-affiliated OTUs (Figures 4A,B). However, the minimally abundant phylotypes (Figure 4B) detected in the "fresh" waters were not detected in the slurries, despite similar sampling effort (Figure 2). Indeed, only four (B-U1 $\left.1_{\text {slurry }}, \mathrm{C}-\mathrm{U} 1_{\text {slurry }}\right)$ or five (A-U1 $1_{\text {slurry }}, A-U 2_{\text {slurry }}$, B-U2 $2_{\text {slurry }}, \mathrm{C}-\mathrm{U} 2_{\text {slurry }}, \mathrm{D}-\mathrm{U} 1_{\text {slurry }}$ ) unique phyla were detected in absorber slurries (Figure 4C). Bacteroidetes-affiliated OTUs, which comprised $\geq 10 \%$ of OTUs detected in "fresh" waters, were only detected in D-U1 $1_{\text {slurry }}$ and E-U1 $1_{\text {slurry }}$ (Figure 1). Firmicutes, which generally comprised a relatively small fraction of the total OTUs in "fresh" waters, were enriched in B-U1 $1_{\text {slurry }}, \mathrm{B}-\mathrm{U} 2_{\text {slurry }}$, $\mathrm{C}-\mathrm{U} 2_{\text {slurry }}$, and E-U1 $1_{\text {slurry }}$ (Figures 4A,C).

Genus-level assignments that could be made to OTUs detected in absorber slurries were examined in more detail and are presented in Table A1. While many of the genera that were abundant in absorber slurries contained halophilic and/or thermophilic representatives (Table A1), these genera are also routinely detected in less "extreme" settings, including soils, freshwater, and marine aquatic settings, and associated with plant and animal hosts. Salinicoccus- and Jeotgalicoccus-affiliated phylotypes were detected in $\mathrm{B}-\mathrm{U} 1_{\text {slurry }}$ and $\mathrm{C}-\mathrm{U} 2_{\text {slurry }}$, respectively, and these are the only genera that are composed exclusively of halophilic species, though these genera are poorly represented in culture (Yoon et al., 2003; Hoyles et al., 2004; Claus et al., 2006; Guo et al., 2010; Liu et al., 2011; Martin et al., 2011). The majority of genera detected in the absorber slurries were aerobic or facultatively anaerobic organotrophic bacteria (Table A1), except for Limnobacter- (A-U1 $1_{\text {slurry }}$ and A-U2 $\left.2_{\text {slurry }}\right)$ and Cyanobacteria Group VIII-affiliated (A-U2 $2_{\text {slurry }}$ ) phylotypes (Table A1). Limnobacter spp. are aerobic sulfur-oxidizing bacteria and may metabolize partially oxidized sulfur species in the absorber unit (Spring et al., 2001; Lu et al., 2010). The abundance of Cyanobacteria-affiliated OTUs in A-U2 $2_{\text {slurry }}$ was surprising since slurries are not exposed to sunlight, but this unit had started operation $\sim 1$ month before samples were collected, so their presence may be attributable to the source water used to fill the absorber unit. Given the cosmopolitan genera associated with the absorber slurries, the slurry-associated microbial communities appear to be a partial reflection of the "fresh" water-associated microbial communities. The high temperature and solute concentrations of the absorber units induce shifts in the microbial communities, but these shifts may be minimized by the continuous cycling of fluids into and out of the absorber unit as well as the continuous replenishment of "fresh" water.

\section{EVALUATION OF TAXA IN SCALES}

While there appeared to be similarities between the "fresh" waterand absorber slurry-associated microbial communities, UniFracbased evaluation of the microbial communities indicated that scale-associated microbial communities were dramatically different from "fresh" waters or absorber slurries (Figure 3). These differences were also evident in the genera present in the scales. Genus-level assignments could only be made for $\sim 20 \%$ of the sequences recovered from the scale samples (Table 3 ), and in several cases, the numerically dominant OTUs within a phylum could not be resolved beyond the phylum-level using the RDP classifier function (e.g., Betaproteobacteria in A-U2 $2_{\text {scale }}$ and Firmicutes in B-U2 $\left.2_{\text {scale }}\right)$. As such, unresolvable OTUs were evaluated in more detail using BLASTN (Altschul et al., 1990) to compare these OTUs to sequences in the GenBank database. While phyla associated with "fresh" waters and absorber slurries were also detected in scales, more detailed evaluation of 16S rRNA gene sequences recovered from $\mathrm{A}-\mathrm{U} 2_{\text {scale }}$ and $\mathrm{B}-\mathrm{U} 2_{\text {scale }}$ revealed that the majority (80 and $60 \%$, respectively) of the OTUs were attributable to thermophilic lineages.

Four phyla (Bacteroidetes, Betaproteobacteria, DeinococcusThermus, and Firmicutes) comprised $90 \%$ of the OTUs detected in A-U2 scale (Figure 4D). Deinococcus-Thermus-affiliated phylotypes were not detected in any of the "fresh" water or absorber slurries. All Deinococcus-Thermus-affiliated OTUs were Meiothermus- (99\% similar to Meiothermus timidus; Pires et al., 2005) and Thermus- (100\% similar to Thermus scotoductus; Gounder et al., 2011) affiliated phylotypes. Both of these species are thermophilic aerobic organotrophs, and T. scotoductus is capable of anaerobic respiration using $\mathrm{Fe}(\mathrm{III})$ and $S^{0}$ as a terminal electron acceptors (Kieft et al., 1999; Pires et al., 2005). While Bacteroidetes-, Betaproteobacteria-, and Firmicutes-affiliated bacteria were detected in "fresh" water and absorber slurries, the predominant OTUs affiliated with these lineages were quite different from those detected in the "fresh" waters or absorber slurries. The most abundant Bacteroidetesaffiliated OTU in A-U2 scale was $99 \%$ similar to an organism isolated from geothermal soil (Stott et al., 2008). The most abundant Betaproteobacterial OTU in A-U2 $2_{\text {scale }}$ was $92 \%$ similar to Hydrogenophilus thermoluteolus, a thermophilic $\mathrm{H}_{2}$-oxidizing bacterium (Hayashi et al., 1999). The most abundant Firmicutesaffiliated OTU from A-U2 $2_{\text {scale }}$ was $92 \%$ similar to $16 \mathrm{~S}$ rRNA gene sequences recovered from composting operations in the thermophilic phase of operation (Partanen et al., 2010).

Firmicutes-affiliated OTUs were most abundant (61\%)

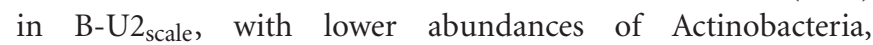
Alphaproteobacteria, Betaproteobacteria, Gammaproteobacteria, Bacteroidetes, and Deinococcus-Thermus (Figure 4D). Approximately $58 \%$ of the total OTUs in B-U2 $2_{\text {scale }}$ were 95\% similar to Alicyclobacillus pohliae, an aerobic, thermophilic Firmicutes isolated from geothermal soils (Imperio et al., 2008). Other thermophilic lineages that were detected in $\mathrm{B}-\mathrm{U} 2_{\text {scale }}$ were Rubrobacter sp. (Stackebrandt and Schumann, 2006), Meiothermus sp. (da Costa et al., 2006), and Thermithiobacillus (Kelly and Wood, 2000), though these phylotypes were present in considerably lower abundances than the Alicyclobacillus-affiliated phylotypes. The remaining phylotypes detected in $\mathrm{B}-\mathrm{U} 2_{\text {scale }}$ were generally cosmopolitan, mesophilic lineages, including phylotypes attributable to Flavobacterium, Hymenobacter, and Mucilaginobacter (Bacteroidetes), Corynebacterium and Arthrobacter (Actinobacteria), Pelomonas (Betaproteobacteria), 
Stenotrophomonas and Pseudomonas (Gammaproteobacteria), and Rhodospirillum and Novosphingobium (Alphaproteobacteria), which were also detected in "fresh" waters and absorber slurries.

\section{DISCUSSION \\ IMPLICATIONS FOR WET FGD SYSTEM OPERATION AND PERFORMANCE}

We observed three microbial community types associated with limestone forced air oxidation wet FGD systems that appeared to be controlled by the prevailing physicochemical conditions specific to the three process points evaluated in the FGD systems. Microbial communities associated with source and makeup waters were numerically dominated by phylotypes associated with mesophilic lineages of Actinobacteria, Bacteroidetes, Firmicutes, Alphaproteobacteria, Betaproteobacteria, and Gammaproteobacteria (Figure 4A), with similar phylum-level profiles to freshwater lakes and rivers (Burkert et al., 2003; Allgaier and Grossart, 2006; Newton et al., 2007; Mueller-Spitz et al., 2009; Clingenpeel et al., 2011). Absorber slurry-associated microbial communities, which were exposed to higher dissolved solid concentrations and periodically higher temperatures, shared some characteristics with "fresh" FGD process waters, but were considerably less diverse. Absorber slurry microbial communities were numerically dominated by Actinobacteria-, Alphaproteobacteria-, Betaproteobacteria-, and Gammaproteobacteria-affiliated phylotypes, though the minimally abundant phylotypes that were detected in the "fresh" FGD process waters were not detected in absorber slurries, despite robust sampling effort. These results suggest that absorber slurryassociated microbial communities retain characteristics of "fresh" FGD process waters, but that the more extreme physicochemical conditions inside the absorber unit induce shifts in the microbial communities. Indeed, the finding of higher numbers of culturable halothermophilic/tolerant bacteria in absorber slurries than in "fresh" FGD process waters supports the hypothesis that "fresh" FGD process water-associated microbial communities adapt to the higher solute concentrations and temperatures of the FGD absorber units. The slurry-associated microbial community structure appears to be retained when slurry waters are treated and returned to circulation as reuse water. Despite the chemical similarities of $\mathrm{B}-\mathrm{U} 1_{\text {reuse }}$ to other "fresh" process

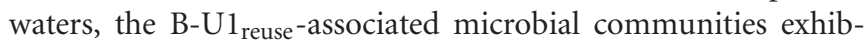
ited diversity and UniFrac characteristics that were more similar to those of absorber slurry-associated communities, and retained relatively high numbers of culturable halothermophilic/tolerant microorganisms.

While absorber slurry-associated microbial communities differ from "fresh" water-associated communities, the retention of some phylotypes is attributable to the dynamics of absorber operation. Absorber units are initially filled with fresh waters, and during unit operation, the slurries are continuously circulated through the system (Figure 1). Slurry residence times in absorber units are typically 10-20 h (Sargent and Lundy, 2003), though this may vary depending on absorber unit size and design. Heat from the flue gas maintains temperatures of $50-80^{\circ} \mathrm{C}$ in the absorber unit, while fluids outside the unit (i.e., circulating slurry, freshly prepared limestone-water slurry, and source water) are subjected to ambient air temperatures (yearly averages of $10-15^{\circ} \mathrm{C}$ in the Midwestern United States). When slurries circulate out of the absorber units, they return to ambient temperature while a portion of slurry is diverted for gypsum recovery and water treatment. Slurry that is to be returned to the absorber unit is then amended with fresh limestone and "topped-off" with makeup or reuse water to account for fluid lost to gypsum recovery and evaporation (Figure 1). As such, slurry-associated microbial communities are not continuously exposed to high temperature, and are replenished with organisms associated with "fresh" FGD process waters.

Surprisingly few of the phylotypes detected in the FGD absorber slurries were affiliated with sulfur-metabolizing lineages, despite the abundance of sulfate (and likely partially reduced $\mathrm{S}$ species) and the application of robust sampling effort. The only phylotype detected in absorber slurries that was affiliated with an S-metabolizing bacterial lineage was attributable to S-oxidizing Limnobacter spp. in A-U1 $1_{\text {slurry }}$ (Table A1). Low numbers of phylotypes attributable to reduced S-oxidizing Thiobacillus spp., Thiothrix spp. (Lane et al., 1992), and Rhodopseudomonas spp. (Then and Trüper, 1981) were detected in "fresh" FGD process waters, but not in slurries. Similarly, phylotypes attributable to Firmicutes- and Deltaproteobacteria-affiliated sulfate-reducing bacteria (Muyzer and Stams, 2008) were detected in low numbers in "fresh" waters, but not at all in absorber slurries or scales. In thermal settings, $S$ metabolism may be mediated by Archaea (Amend and Shock, 2001), which were not evaluated in this study, but the majority of phylotypes detected in the slurries were affiliated with aerobic organotrophic lineages (Table A1). Given the abundant organic carbon supplied by flue gas and abundant $\mathrm{O}_{2}$ supplied by forced air, it appears that aerobic organotrophy is the major mode of bacterial metabolism in the FGD slurries.

Scale-associated microbial communities were quite distinct from those of "fresh" FGD process waters and absorber slurries, with abundant phylotypes associated with thermophilic bacterial lineages. Microorganisms associated with absorber slurries are periodically exposed to temperatures of $50-80^{\circ} \mathrm{C}$, but the duration of exposure to high temperature is apparently insufficient to induce shifts to the thermophilic microbial communities that we observed in scales recovered from FGD absorber walls. While microbial communities associated with both A-U2 $2_{\text {scale }}$ and $\mathrm{B}-\mathrm{U} 2_{\text {scale }}$ were numerically dominated by thermophilic phylotypes, there were differences between the communities. A-U2 $2_{\text {scale }}$ included 16S rRNA gene sequences related to Hydrogenophilus, Thermus, and Meiothermus species as numerically dominant phylotypes, while the majority of 16S rRNA gene sequences detected in B-U2 $2_{\text {scale }}$ were attributable to the genus Alicyclobacillus.

The source of the thermophilic bacteria detected in the scales is unclear. Endolithic thermophiles entrained in the limestone feed (Amend and Shock, 2001; Horath and Bachofen, 2009) may have served as an inoculum for the scales, though we were unable to obtain limestone samples from the power generation facilities. It is notable that the thermophilic lineages detected in the scales were not detected in the "fresh" waters, or even in the slurries. The detection of mesophilic phylotypes in scales suggests some influence of the "fresh" process water microbial communities on scale-associated community composition, and it is possible 
that thermophiles were present in "fresh" waters, but were not detected in due to the application of insufficient sampling effort to "fresh" waters. Thermophilic bacteria have been isolated from temperate soils, and may maintain some level of metabolic activity at relatively low temperatures (i.e., $\leq 25^{\circ} \mathrm{C}$; Marchant et al., 2002, 2008; Hubert et al., 2010; Portillo et al., 2012). These findings suggest that some thermophilic microorganisms may be cosmopolitan components of non-thermal ecosystems (albeit in low abundance), as members of the "rare biosphere" (Sogin et al., 2006; Elshahed et al., 2008; Galand et al., 2009). Indeed, Thermus-affiliated species were isolated from hot-water heaters that received water from municipal wells (Brock and Boylen, 1973), suggesting that non-thermal source waters may provide an inoculum for the thermophilic scale-associated communities. While halothermophilic/tolerant organisms were not detected in $\mathrm{A}_{\text {source}}$, they were detected in low abundances in several of the makeup and reuse water samples (Table 3 ).

The corrosion of steel structures associated with FGD systems is an increasingly prevalent problem (Mansfield and Jeanjaquet, 1987; Hibner and Ross, 1988; Bordziłowski and Darowicki, 1998; Kim et al., 2010). The high solute concentrations and DO of the absorber unit fluids makes them aggressively corrosive solutions, and may give rise to severe pitting corrosion, which has been reported for FGD structures (including systems evaluated in this study) and is often associated with MIC (Franklin et al., 1991; Strehblow, 2007; Moskal, 2011). The FGD units at Facility A have not yet experienced serious corrosion problems, but Facility B units have experienced severe problems with corrosion, despite the fact that both units were constructed using the same type of steel. The potential for MIC in FGD systems has been recognized, though studied in minimal detail (Moskal, 2011), and it is difficult to definitively determine the contribution of MIC to the deterioration of the absorber units at Facility B or industrywide. Nevertheless, any MIC occurring in FGD systems is likely to be driven primarily by the distinct thermophilic microbial communities that develop on steel surfaces in the absorber unit wall scale.

Both $\mathrm{A}-\mathrm{U} 2_{\text {scale }}$ and $\mathrm{B}-\mathrm{U} 2_{\text {scale }}$ contained abundant phylotypes attributable to thermophilic bacterial lineages, but the metabolism of organisms associated with the lineages are quite different. Cultured representatives of the genera Meiothermus and Thermus are obligately aerobic organotrophs (Loginova et al., 1984; Tenreiro et al., 1995; Chung et al., 1997; Chen et al., 2002;

\section{REFERENCES}

Allgaier, M., and Grossart, H.-P. (2006). Diversity and seasonal dynamics of Actinobacteria populations in four lakes in Northeastern Germany. Appl. Environ. Microbiol. 72, 3489-3497.

Altschul, S. F., Gish, W., Miller, W., Myers, E. W., and Lipman, D. J. (1990). Basic local alignment search tool. J. Mol. Biol. 215, 403-410.

Amend, J. P., and Shock, E. L. (2001). Energetics of overall metabolic reactions of thermophilic and hyperthermophilic Archaea and
Bacteria. FEMS Microbiol. Rev. 25, 175-243.

Bordziłowski, J., and Darowicki, K. (1998). Anti-corrosion protection of chimneys and flue gas ducts. Anti-Corrosion Methods Mater. 45, 388-396.

Brock, T. D., and Boylen, K. L. (1973). Presence of thermophilic bacteria in laundry and domestic hot-water heaters. Appl. Microbiol. 25, 72-76.

Burkert, U., Warnecke, F., Babenzien, D., Zwirnmann, E., and Pernthaler, J. (2003). Members of a readily enriched Proteobacterial clade

Pires et al., 2005; da Costa et al., 2006), though Thermus scotoductus is a facultative anaerobe capable of oxidation of organic carbon or $\mathrm{H}_{2}$ with $\mathrm{Fe}$ (III) reduction (Kieft et al., 1999), and cultured representatives of the genus Hydrogenophilus are aerobic $\mathrm{H}_{2}$ oxidizing thermophiles (Hayashi et al., 1999). Hydrogenotrophic consumption of cathodically produced $\mathrm{H}_{2}$ is a major mechanism of steel corrosion under anaerobic conditions (Kielemoes et al., 2000; Jack, 2002; Uchiyama et al., 2010; Davidova et al., 2012), but the role of this process under aerobic conditions is unclear, and it appears unlikely to be occurring to any substantial extent in A-U $2_{\text {scale, }}$, since no corrosion has been reported at this facility thus far. Alicyclobacillus species, such as those detected in B-U2 $2_{\text {scale }}$, metabolize carbohydrates to organic acids, and several species oxidize $\mathrm{Fe}(\mathrm{II})$ and reduced sulfur species (Dufresne et al., 1996; Jiang et al., 2008; Imperio et al., 2008; Guo et al., 2009). The abundance of phylotypes attributable to Alicyclobacillus in B-U2 $2_{\text {scale }}$ is quite striking, and both organotrophic (organic acid production) and lithotrophic ( $\mathrm{Fe}(\mathrm{II})$ oxidation) activities are substantial contributors to steel corrosion (Rao et al., 2000; Starosvetsky et al., 2001; Pecar et al., 2011). Indeed, slightly higher Fe(III) concentrations were detected in B-U2 $2_{\text {scale }}$ than in A-U2 $2_{\text {scale }}$ (Table 2), which may indicate $\mathrm{Fe}(\mathrm{II})$-oxidizing activities.

Our results suggest that unique microbial communities develop in physicochemically distinct process points within FGD systems. Microbial communities associated with makeup waters have characteristics typical of freshwater bodies. Microbial communities associated with slurries bear some resemblance to the makeup waters, but are influenced by the high dissolved solute concentration of the slurry fluids, giving rise to more abundant halophilic/tolerant microorganisms. Microbial communities associated with scale deposits are quite unique, with abundant phylotypes attributable to thermophilic bacterial lineages. Ultimately, activities of the scale-associated microbial communities will be the predominant drivers of MIC in FGD systems, and the dynamics of their activities will need to be evaluated in more detail to determine their contribution to the corrosion of steel structures within these facilities.

\section{ACKNOWLEDGMENTS}

This work was funded by the Babcock \& Wilcox Power Generation Group, Inc. We thank the operators of the electric power generation facilities for allowing us to collect samples from their FGD systems.

are common in surface waters of a humic lake. Appl. Environ. Microbiol. 69, 6550-6659.

Caporaso, J. G., Bittinger, K., Bushman, F. D., DeSantis, T. Z., Andersen, G. L., and Knight, R. (2010a). PyNAST: a flexible tool for aligning sequences to a template alignment. Bioinformatics 26, 266-267.

Caporaso, J. G., Kuczynski, J., Stombaugh, J., Bittinger, K., Bushman, F. D., Costello, E. K., et al. (2010b). QIIME allows analysis of high-throughput community sequence data. Nat. Methods 7, 335-336.

Chen, M.-Y., Lin, G.-H., Lin, Y.-T., and Tsay, S.-S. (2002). Meiothermus taiwanensis sp. nov., a novel filamentous, thermophilic species isolated in Taiwan. Int. J. Syst. Evol. Microbiol. 52, 1647-1654.

Chung, A. P., Rainey, F., Nobre, M. F., Burghardt, J., and da Costa, M. S. (1997). Meiothermus cereberus sp. nov., a new slightly thermophilic species with high levels of 3-Hydroxy Fatty Acids. Int. J. Syst. Evol. Microbiol. 47, 1225-1230. 
Claus, D., Fritze, D., and Kocur, M. (2006). "Genera related to the genus Bacillus - Sporolactobacillus, Sporosarcina, Planococcus, Filibacter and Caryophanon," in The Prokaryotes. Bacteria: Firmicutes, Cyanobacteria, Vol. 4, 3rd Edn, eds M. Dworkin, S. Falkow, E. Rosenberg, H.-K. Schleifer, and E. Stackebrandt (New York, NY: Springer), 631-653.

Clingenpeel, S., Macur, R. E., Kan, J., Inskeep, W. P., Lovalvo, D., Varley, J., et al. (2011). Yellowstone Lake: high-energy geochemistry and rich bacterial diversity. Environ. Microbiol. 13, 2172-2185.

Cole, J. R., Wang, Q., Cardenas, E., Fish, J., Chai, B., Farris, R. J., et al. (2009). The Ribosomal Database Project: improved alignments and new tools for rRNA analysis. Nucleic Acids Res. 37(Suppl. 1), D141-D145.

Colwell, R. R. (1979). "Enumeration of specific populations by most-probable number (MPN) method," in Native Aquatic Bacteria: Enumeration, Activity, and Ecology, eds J. W. Costerton and R. R. Colwell (Philadelphia, PA: American Society for Testing and Materials), 56-61.

Cooper, I., and Ruocco, R. (2010). "Wastewater treatment for flue gas desulfurization at electric power plants," in Paper Presented at the NC AWWA-WEA 90th Annual Conference, (Winston-Salem, NC).

Cullis, C. F., and Hirschler, M. M. (1980). Atmospheric sulphur: natural and man-made sources. Atmos. Environ. 14, 1263-1278.

da Costa, M. S., Rainey, F. A., and Nobre, M. F. (2006). "The genus Thermus and relatives," in The Prokaryotes: Volume 7, Proteobacteria: Delta, Epsilon Subclass, 3rd Edn, eds M. Dworkin, S. Falkow, E. Rosenberg, H.-K. Schleifer, and E. Stackebrandt (New York, NY: Springer), 797-814.

Dasu, B. N., Deshmane, V., Shanmugasundram, R., Lee, C.-M., and Sublette, K. L. (1993). Microbial reduction of sulfur dioxide and nitric oxide. Fuel 72, 1705-1714.

Davidova, I. A., Duncan, K. E., Perez-Ibarra, B. M., and Suflita, J. M. (2012). Involvement of thermophilic archaea in the biocorrosion of oil pipelines. Environ. Microbiol. 14, 1762-1771.

DeSantis, T. Z., Hugenholtz, P., Larsen, N., Rojas, M., Brodie, E. L., Keller, K., et al. (2006). Greengenes, a chimera-checked 16S rRNA gene database and workbench compatible with ARB. Appl. Environ. Microbiol. 72, 5069-5072.

Dowd, S. E., Callaway, T. R., Wolcott, R. D., Sun, Y., McKeehan, T., Hagevoort, R. G., et al. (2008). Evaluation of the bacterial diversity in the feces of cattle using $16 \mathrm{~S}$ rDNA bacterial tag-encoded FLX amplicon pyrosequencing (bTEFAP). BMC Microbiol. 8:125. doi: 10.1186/14712180-8-125

Dufresne, S., Bousquet, J., Boissinot, M., and Guay, R. (1996). Sulfobacillus disulfidooxidans sp. nov., a new acidopilic disulfideoxidizing, gram positive, spore forming bacterium. Int. J. Syst. Evol. Microbiol. 46, 1056-1064.

Edgar, R. C. (2010). Search and clustering orders of magnitude faster than BLAST. Bioinformatics 26, 2460-2461.

Elshahed, M. S., Youssef, N. H., Spain, A. M., Sheik, C., Najar, F. Z., Sukharnikif, L. O., et al. (2008). Novelty and uniqueness patterns of rare members of the soil biosphere. Appl. Environ. Microbiol. 74, 5422-5428.

Franklin, M. J., White, D. C., and Isaacs, H. S. (1991). Pitting corrosion by bacteria on carbon steel, determined by the scanning vibrating electrode technique. Corros. Sci. 32, 945-952.

Galand, P. E., Casamayor, E. O., Kirchman, D. L., and Lovejoy, C. (2009). Ecology of the rare microbial biosphere of the Arctic Ocean. Proc. Natl. Acad. Sci. U.S.A. 106, 22427-22432.

Gontcharova, V. Y., Wolcott, R. D., Hollister, E. B., Gentry, T. J., and Dowd, S. E. (2010). Black Box Chimera Check (B2C2): a windowsbased software for batch depletion of chimeras from bacterial 16S rRNA gene datasets. Open Microbiol. J. 4, 6.

Gounder, K., Brzukiewicz, E., Liesegang, H., Wollherr, A., Daniel, R., Gottschalk, G., et al. (2011). Sequence of the hyperplastic genome of the naturally competent Thermus scotoductus SA-01. BMC Genomics 12:577. doi: 10.1186/1471-2164-12-577

Greenberg, A. E., Connors, J. J., Jenkins, D., and Franson, M. A. H. (eds.). (1981). Standard Methods for the Examination of Water and Wastewater, 15th Edn. Washington, DC: American Public Health Association, American Water Works Association, and Water Pollution Control Federation.

Guo, X., You, X.-Y., Liu, L.-J., Zhang, J.Y., Liu, S.-J., and Jiang, C.-Y. (2009). Alicyclobacillus aeris sp. nov., a novel ferrous- and sulfur-oxidizing bacterium isolated from a copper mine. Int. J. Syst. Evol. Microbiol. 59, 2415-2420.

Guo, X.-Q., Li, R., Zheng, L.-Q., Lin, D.-Q., Sun, J.-Q., Li, S.-P., et al. (2010). Jeotgalicoccus huakuii sp. nov., a halotolerant bacterium isolated from seaside soil. Int. J. Syst. Evol. Microbiol. 60, 1307-1310.

Hayashi, N. R., Ishida, T., Yokota, A., Kodama, T., and Igarashi, Y. (1999). Hydrogenophilus thermoluteolus gen. nov., sp. nov., a thermophilic, facultatively chemolithoautotrophic, hydrogen oxidizing bacterium. Int. J. Syst. Evol. Microbiol. 49, 783-786.

Hibner, E. L., and Ross, R. W. Jr. (1988). Localized corrosion behavior of nickel alloys in model $\mathrm{SO}_{2}$ scrubber environments. Corrosion 44, 404-411.

Horath, T., and Bachofen, R. (2009). Molecular characterization of an endolithic microbial community in dolomite rock in the Central Alps (Switzerland). Environ. Microbiol. 58, 290-306.

Hoyles, L., Collins, M. D., Foster, G., Falsen, E., and Schumann, P. (2004). Jeotgalicoccus pinnipedalis sp. nov., from a southern elephant seal (Mirounga leonina). Int. J. Syst. Evol. Microbiol. 54, 745-748.

Huber, H., and Stetter, K. O. (1998). Hyperthermophiles and their possible potential in biotechnology. J. Biotechnol. 64, 39-52.

Hubert, C., Arnosti, C., Brüchert, V., Loy, A., Vandieken, V., and Jørgensen, B. B. (2010). Thermophilic anaerobes in Arctic marine sediments induced to mineralize complex organic matter at high temperature. Environ. Microbiol. 12, 1089-1104.

Imperio, T., Viti, C., and Marri, L. (2008). Alicyclobacillus pohliae, sp. nov., a thermophilic, endosporeforming bacterium isolated from geothermal soil of the northwest slope of Mount Melbourne (Antarctica). Int. J. System. Evol. Microbiol. 58, 221-225.

Jack, T. R. (2002). "Biological corrosion failures," in ASM Handbook: Volume 11, Failure Analysis and Prevention, eds W. T. Becker and R. J. Shipley (Materials Park, OH: ASM International), 881-898.

Jiang, C.-Y., Liu, Y., Liu, Y.-Y., You, X.-Y., Guo, X., and Liu, S.-J. (2008). Alicyclobacillus ferrooxydans sp. nov., a ferrous-oxidizing bacterium from solfataric soil. Int. J. Syst. Evol. Microbiol. 58, 2898-2903.

Kelly, D. P., and Wood, A. P. (2000). Reclassification of some species of
Thiobacillus to the newly designated genera Acidithiobacillus gen. nov., Halothiobacillus gen. nov. and Thermithiobacillus gen. nov. Int. J. System. Evol. Microbiol. 50, 511-516.

Kieft, T. L., Fredrickson, J. K., Onstott, T. C., Gorby, Y. A., Kostandarithes, H. M., Bailey, T. J., et al. (1999) Dissimilatory reduction of $\mathrm{Fe}$ (III) and other electron acceptros by a Thermus isolate. Appl. Environ. Microbiol. 65, 1214-1221.

Kielemoes, J., De Boever, P., and Verstraete, W. (2000). Influence of denitrification on the corrosion of iron and stainless steel powder. Environ. Sci. Technol. 34, 663-671.

Kiil, S., Michelsen, M. L., and DamJohansen, K. (1998). Experimental investigation and modeling of a wet flue gas desulfurization pilot plant. Ind. Eng. Chem. Res. 37, 2792-2806.

Kim, M. J., Lee, S. H., Kim, J. G., and Yoon, J. B. (2010). Effect of phosphorous on the corrosion behavior of carbon steel in sulfuric acid. Corrosion 66, 125005-125005-9.

Kitto, J. B., and Stultz, S. C. (eds.). (2005). Steam: Its Generation and Use, 41st Edn. Barberton, OH: The Babcock and Wilcox Company.

Lane, D. J., Harrison, A. P. Jr., Stahl, D., Pace, B., Giovannoni, S. J., Olsen, G. J., et al. (1992). Evolutionary relationships amond sulfur- and ironoxidizing eubacteria. J. Bacteriol. 174, 269-278.

Liu, Z. X., Chen, J., Tang, S. K., Zhang, Y. Q., He, J. W., Chen, Q. H., et al. (2011). Jeotgalicoccus nanhaiensis sp. nov., isolated from intertidal sediment, and emended decription of the genus Jeotgalicoccus. Int. J. Syst. Evol. Microbiol. 61, 2029-2034.

Loginova, L. G., Egrova, L. A., Golovacheva, R. S., and Seregina, L. M. (1984). Thermus ruber sp. nov., nom. rev. Int. J. Syst. Evol. Microbiol. 34, 498-499.

Lovley, D. R., and Phillips, E. J. P. (1987). Rapid assay for microbially reducible ferric iron in aquatic sediments. Appl. Environ. Microbiol. 53, 1536-1540.

Lozupone, C., and Knight, R. (2005). UniFrac: a new phylogenetic method for comparing microbial communities. Appl. Environ. Microbiol. 71, 8228-8235.

Lu, H., Sato, Y., Fujimura, R., Nishizawa, T., Kamijo, T., and Ohta, H. (2010). Limnobacter litoralis sp. nov., a thiosulfateoxidizing, heterotrophic bacterium isolated from a volcanic deposit, and emended description of the genus Limnobacter. Int. J. Syst. Evol. Microbiol. 60, 404-407. 
Mansfield, F., and Jeanjaquet, S. L. (1987). Effects of trace elements on the corrosion behavior or flue gas desulfurization materials. Corrosion 43, 298-304.

Marchant, R., Banat, I. M., Rahman, T. J., and Berzano, M. (2002). The frequency and characteristics of highly thermophilic bacteria in cool soil environments. Environ. Microbiol. 4, 595-602.

Marchant, R., Franzetti, A., Pavlostathis, S. G., Tas, D. O., Erdbrügger, I., Ünyayar, A., et al. (2008). Thermophilic bacteria in cool temperate soils: are they metabolically active or continually added by global atmospheric transport? Appl. Microbiol. Biotechnol. $78,841-852$

Martin, E., Klug, K., Frischmann, A., Busse, H. J., Kämpfer, P., and Jäckel, U. (2011). Jeotgalicoccus coquina sp. nov. and Jeotgalicoccus aerolatus sp. nov., isolated from poultry houses. Int. J. Syst. Evol. Microbiol. 61, 237-241.

Moskal, M. (2011). EPRI corrosion of wet flue gas desulfurization systems. Conduit 11, 1-2.

Mueller-Spitz, S. R., Goetz, G. W., and McLellan, S. L. (2009). Temporal and spatial variability in nearshore bacterioplankton communities of Lake Michigan. FEMS Microbiol. Ecol. 67, 511-522.

Muyzer, G., and Stams, A. J. M. (2008). The ecology and biotechnology of sulfate-reducing bacteria. Nat. Rev. Microbiol. 6, 441-454.

Newton, R. J., Jones, S. E., Helmus, M. R., and McMahon, K. D. (2007). Phylogenetic ecology of the freshwater Actinobacteria acI lineage. Appl. Environ. Microbiol. 73, 7169-7176.

Nygaard, H. G., Kiil, S., Johnsson, J. E., Jensen, J. N., Hansen, J., Fogh, F., et al. (2004). Full-scale measurements of $\mathrm{SO}_{2}$ gas phase concentrations and slurry compositions in a wet flue gas desulfurization spray absorber. Fuel 83, 1151-1164.

Pandy, R. A., Biswas, R., Chakrabarti, T., and Devotta, S. (2005). Flue gas desulfurization: physicochemical and biotechnological approaches. Crit. Rev. Environ. Sci. Technol. 35, 571-622.

Parshina, S. N., Kijlstra, S., Henstra, A. M., Sipma, J., Plugge, C. M., and Stams, A. J. M. (2005). Carbon monoxide conversion by thermophilic sulfate-reducing bacteria in pure culture and in co-culture with Carboxydothermus hydrogenoformans. Appl. Microbiol. Biotechnol. 68, 390-396.

Parshina, S. N., Sipman, J., Henstra, A. M., and Stams, A. J. M. (2010). Carbon monoxide as an electron donor for biological reduction of sulfate. Int. J. Microbiol. 2010, 319527.

Partanen, P., Hultman, J., Paulin, L., Auvinen, P., and Romantschuk, M. (2010). Bacterial diversity at different stages of the composting process. BMC Microbiol. 10:94. doi: 10.1186/1471-2180-10-94

Pecar, D., Slemnik, M., and Gorsek, A. (2011). Testing the corrosion resistance of stainless steels during the fermentation of probiotic drink. J. Sci. Food Agric. 91, 1293-1297.

Pires, A. L., Albuquerque, L., Tiaga, I., Nobre, M. F., Empadinhas, N., Veríssimo, A., et al. (2005). Meiothermus timidus sp. nov., a new slightly thermophilic yellow pigmented species. FEMS Microbiol. Lett. 245, 39-45.

Portillo, M. C., Santana, M., and Gonzalez, J. M. (2012). Presence and potential role of thermophilic bacteria in temperate terrestrial environments. Naturwissenschaften 99, 43-53.

Rajendran, N., Latha, G., Ravichandran, K., and Rajeswari, S. (1999). Flue gas desulfurization systems - a review. Corros. Rev. 17, 443-465.

Rao, T. S., Sairam, T. N., Viswanathan, B., and Nair, K. V. K. (2000). Carbon steel corrosion by iron oxidizing and sulphate reducing bacteria in a freshwater cooling system. Corros. Sci. 42, 1417-1430.

Saini-Eidukat, B., and Yahin, A. (1999). Web-phreeq: a WWW instructional tool for modeling the distribution of chemical species in water. Comput. Geosci. 25, 347-353.

Sargent, and Lundy, L. L. C. (2003). Wet Flue Gas Desulfurization Technology Evaluation. Project Number 11311-000, Prepared for National Lime Association, Chicago, IL. Available online at: www.graymont.com/technical/Wet FlueGasDesulfurization Technology Evaluation.pdf

Sogin, M. L., Morrison, H. G., Huber, J. A., Welch, D. M., Huse, S. M., Neal, P. R., et al. (2006). Microbial diversity in the deep sea and the underexplored "rare biosphere." Proc. Natl. Acad. Sci. U.S.A. 103, 12115-12120. Spring, S., Kämpfer, P., and Schleifer, K. H. (2001). Limnobacter thiooxidans gen. nov., sp. nov., a novel thiosulfate-oxidizing bacterium isolated from freshwater lake sediment. Int. J. Syst. Evol. Microbiol. 51, 1463-1470.

Stackebrandt, E., and Schumann, P. (2006). "Introduction to the taxonomy of Actinobacteria," in The Prokaryotes: Volume 3, Archaea. Bacteria: Firmicutes, Actinomycetes, $3 r d$ Edn. eds M. Dworkin, S. Falkow, E. Rosenberg, H.-K. Schleifer, and E. Stackebrandt (New York, NY: Springer), 297-321.

Starosvetsky, D., Armon, R., Yahalom, J., and Starosvetsky, J. (2001). Pitting corrosion of carbon steel caused by iron bacteria. Int. Biodeterior. Biodegradation 47, 79-87.

Stookey, L. L. (1970). Ferrozine - a new spectrophotometric reagent for iron. Anal. Chem. 42, 779-781.

Stott, M. B., Crowe, M. A., Mountain, B. W., Smirnova, A. V., Hou, S. Alam, M., et al. (2008). Isolation of novel bacteria, including a candidate division from geothermal soild in New Zealand. Environ. Microbiol. 10, 2030-2041.

Strehblow, H. H. (2007). "Pitting corrosion," in Encyclopedia of Electrochemistry, Corrosion and Oxide Films, Vol. 4, eds M. Stratman and G. S. Frankel (Weinheim, Germany: Wiley-UCH GmbH and Co.), 308-343.

Sutter, J. H., Colquitt, K., and Sutter, J. R. (1974). Kinetics of the disproportionation of manganate in acid solution. Inorg. Chem. 13, 1444-1446.

Tanner, R. S. (1997). "Cultivation of bacteria and fungi," in Manual of Environmental Microbiology, eds C. J. Hurst, G. R. Knudsen, M. J. McInerney, L. D. Stetzenbach, and M. V. Walter (Washington, DC: American Society for Microbiology), 52-59.

Templeton, A. S., Staudigel, H., and Tebo, B. M. (2005). Diverse $\mathrm{Mn}(\mathrm{II})$-oxidizing bacteria isolated from submarine basalts at Loihi Seamount. Geomicrobiol. J. 22, 127-139.

Tenreiro, S., Nobre, M. F., and da Costa, M. S. (1995). Thermus silvanus sp. nov. and Thermus chliarophilus sp. nov., two new species related to Thermus ruber but with lower growth temperatures. Int. J. Syst. Bacteriol. 45, 633-639.

Then, J., and Trüper, H. G. (1981). The role of thiosulfate in sulfur metabolism of Rhodopseudomonas globiformis. Arch. Microbiol. 130, 143-146.

Trüper, H. G., and Galinski, E. A. (1986). Concentrated brines as habitats for microorganisms. Experientia 42, 1182-1187.

Uchiyama, T., Ito, K., Mori, K., Tsurumaru, H., and Harayama, S. (2010). Iron-corroding methanogen isolated from a crude-oil storage tank. Appl. Environ. Microbiol. 76, 1783-1788.

Van Ginkel, S. W., Zhou, C., Lien, M., and Rittman, B. E. (2011) Hydrogen-based nitrate and selenite bioreductions in flue-gas desulfurization brine. J. Environ. Eng. 137, 63-68.

Ventosa, A., Nieto, J. J., and Oren, A. (1998). Biology of moderately halophilic aerobic bacteria. Microbiol. Mol. Biol. Rev. 62, 504-544.

Wang, Q., Garrity, G. M., Tiedje, J. M., and Cole, J. R. (2007). Naïve Bayesian classifier for rapid assignment of rRNA sequences into the new bacterial taxonomy. Appl. Environ. Microbiol. 73, 5261-5267.

Yoon, J.-H., Lee, K.-C., Weiss, N., Kang, K. H., and Park, Y.-H. (2003). Jeotgalicoccus halotolerans gen. nov., sp. nov. and Jeotgalicoccus psychrophilus sp. nov., isolated from the traditional Korean fermented seafood jeotgal. Int. J. Syst. Evol. Microbiol. 53, 595-602.

Conflict of Interest Statement: The authors declare that the research was conducted in the absence of any commercial or financial relationships that could be construed as a potential conflict of interest.

Received: 15 August 2012; accepted: 14 November 2012; published online: 30 November 2012.

Citation: Brown BP, Brown SR and Senko JM (2012) Microbial communities associated with wet flue gas desulfurization systems. Front. Microbio. 3:412. doi: 10.3389/fmicb.2012.00412

This article was submitted to Frontiers in Extreme Microbiology, a specialty of Frontiers in Microbiology.

Copyright (C) 2012 Brown, Brown and Senko. This is an open-access article distributed under the terms of the Creative Commons Attribution License, which permits use, distribution and reproduction in other forums, provided the original authors and source are credited and subject to any copyright notices concerning any third-party graphics etc. 


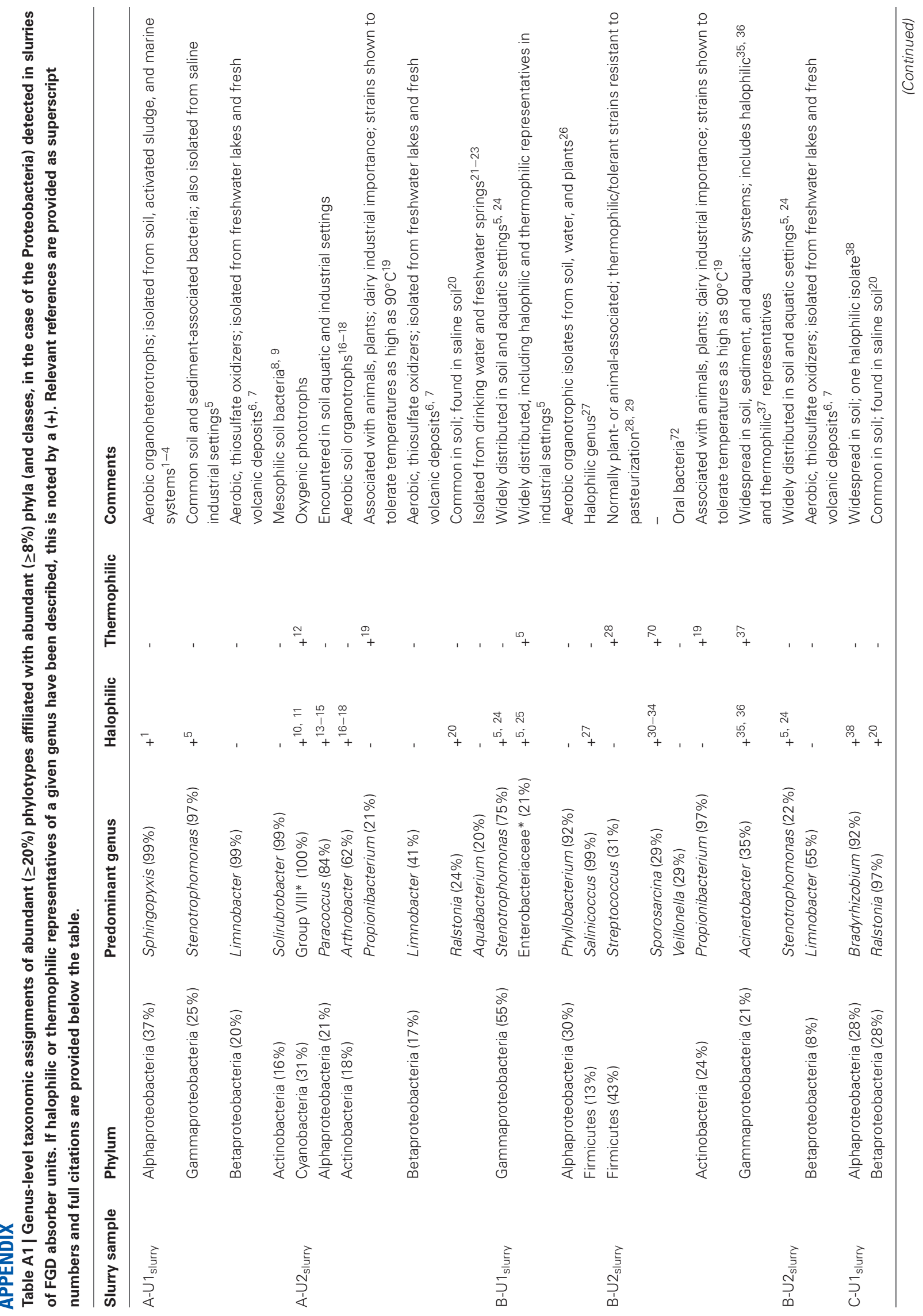




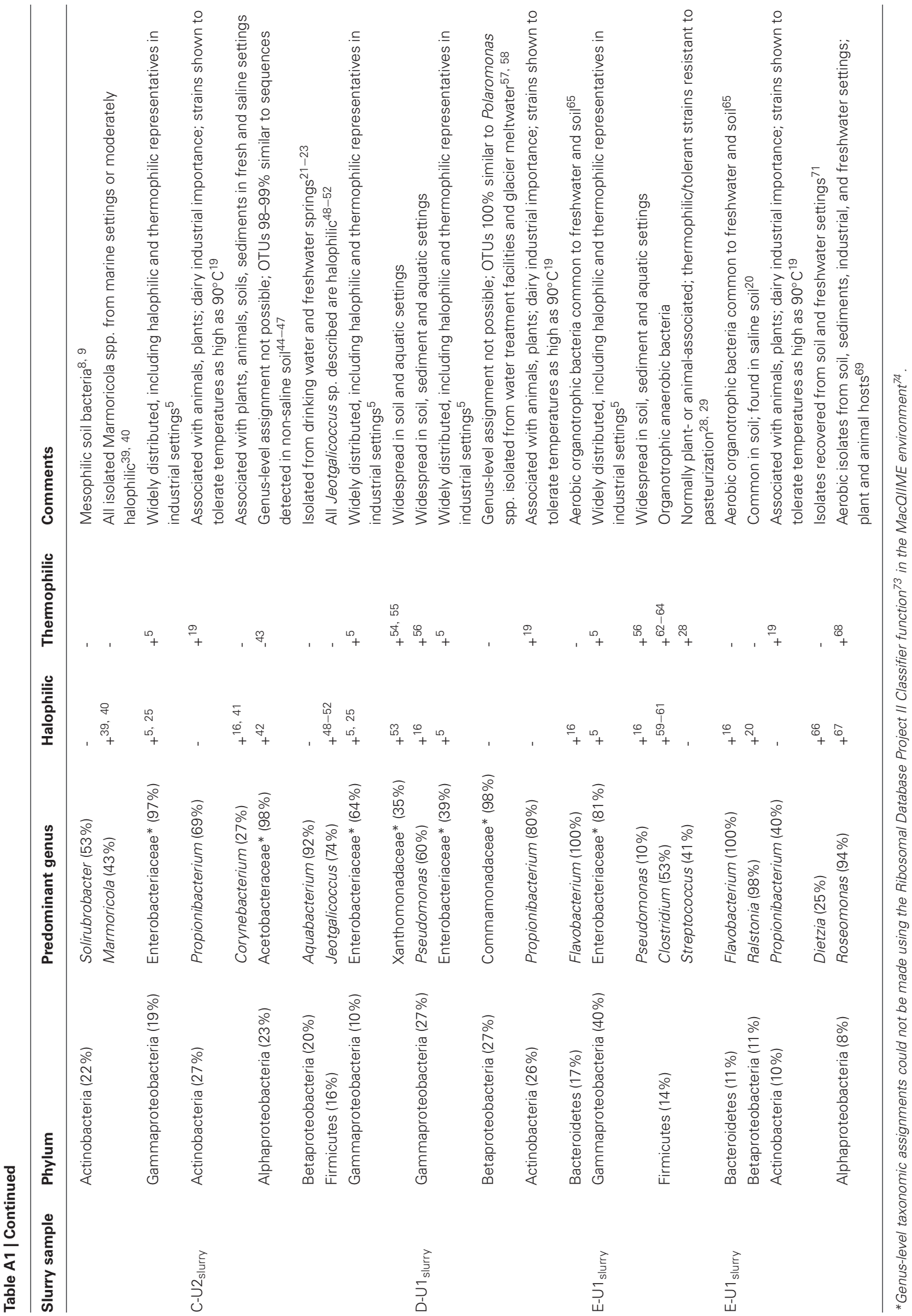




\section{REFERENCES}

${ }^{1}$ Yoon, J.-H., and Oh, T.-K. (2005). Sphingopyxis favimaris sp. nov., isolated from sea water of the Yellow Sea in Korea. Int. J. Syst. Evol. Microbiol. 55, 369-373.

${ }^{2}$ Ting, L., Williams, T. J., Cowley, M. J., Mauro, F. M., Guilhaus, M., Raftery, M. J., et al. (2010). Cold adaptation in the marine bacterium Sphingopyxis alaskensis, assessed using quantitative proteomics. Environ. Microbiol. 12, 2658-2676.

${ }^{3}$ Lee, M., Ten, L. N., Lee, H.-W., Oh, H. W., Im, W.-T., and Lee, S.-T. (2008). Sphingopyxis ginsengsoli sp. nov., isolated from soil of a ginseng field in South Korea. Int. J. Syst. Evol. Microbiol. 58, 2342-2347.

${ }^{4}$ Kämpfer, P., Witzenberger, R., Denner, E. B. M., Busse, H.-J., and Neef, A. (2002). Sphingopyxis witflariensis sp. nov., isolated from activated sludge. Int. J. Syst. Evol. Microbiol. 52, 2029-2034.

${ }^{5}$ Zhuang, X., Han, Z., Bai, Z., Zhuang, G., and Shim, H. (2010). Progress in decontamination by halophilic microorganisms in saline wastewater and soil. Environ. Pollut. 158, 1119-1126.

${ }^{6}$ Spring, S., Kämpfer, P., and Schleifer, K. H. (2001). Limnobacter thiooxidans gen. nov., sp. nov., a novel thiosulfate-oxidizing bacterium isolated from freshwater lake sediment. Int. J. Syst. Evol. Microbiol. 51, 1463-1470.

${ }^{7} \mathrm{Lu}, \quad$ H., Sato, Y., Fujimura, R., Nishizawa, T., Kamijo, T., and Ohta, H. (2010). Limnobacter litoralis sp. nov., a thiosulfateoxidizing, heterotrophic bacterium isolated from a volcanic deposit, and emended description of the genus Limnobacter. Int. J. Syst. Evol. Microbiol. 60, 404-407.

${ }^{8}$ Singleton, D. R., Furlong, M. A., Peacock, A. D., White, D. C., Coleman, D. C., and Whitman, W. B. (2003). Solirubrobacter pauli gen. nov., sp. nov., a mesophilic bacterium within the Rubrobacteridae related to common soil clones. Int. J. Syst. Evol. Microbiol. 53, 485-490.

${ }^{9}$ Kim, M. K., Na, J.-R., Lee, T.-H., Im, W.-T., Soung, N.-K., and Yang, D.-C. (2007). Solirubrobacter soli sp. nov., isolated from soil of a ginseng field. Int. J. Syst. Evol. Microbiol. 57, 1453-1455.

${ }^{10}$ Couradeau, E., Benzerara, K., Moreira, D., Gérard, E., Kazmierczak, J., Tavera, T., et al. (2011). Prokaryotic and eukaryotic community structure in field and cultured microbialites from the alkaline Lake Alchichica (Mexico). PLoS ONE 6:e28767. doi: 10.1371/journal.pone.0028767

${ }^{11}$ Brito, A., Ramos, V., Seabra, R., Santos, A., Santos, C. L., Lopo, M., et al. (2012). Culture-dependent characterization of cyanobacterial diversity in the intertidal zones of the Portuguese coast: a polyphasic study. Syst. Appl. Microbiol. 35, 110-119.

${ }^{12}$ Ionescu, D., Hindiyen, M., Malkawi, H., and Oren, A. (2010). Biogeography of thermophilic cyanobacteria: insights from the Zerka Ma'in hot springs (Jordan). FEMS Microbiol. Ecol. 72, 103-113.

${ }^{13}$ Hochstein, L. I., and Tomlinson, G. A. (1984). The growth of Paracoccus halodenitrificans in a defined medium. Can. J. Microbiol. 30, 837-840.

${ }^{14}$ Lee, J. H., Kim, Y. S., Choi, T.J., Lee, W. J., and Kim, Y. T. (2004). Paracoccus haeundaensis sp. nov., a Gram-negative, halophilic, astaxanthin-producing bacterium. Int. J. Syst. Evol. Microbiol. 54, 1699-1702

${ }^{15}$ Wang, Y., Tang, S.-K., Lou, K., Mao, P.-H., Jin, X., Jiang, C.-L., et al. (2009). Paracoccus saliphilus sp. nov., a halophilic bacterium isolated from a saline pool. Int. J. Syst. Evol. Microbiol. 59, 1924-1928.

${ }^{16}$ Ventosa, A., Nieto, J. J., and Oren, A. (1998). Biology of moderately halophilic aerobic bacteria. Microbiol. Mol. Biol. Rev. 62, 504-544.

${ }^{17}$ Reddy, G. S. N., Aggarwal, R. K., Matsumoto, G. I., and Shival, S. (2000). Arthrobacter flavus sp. nov., a psychrophilic bacterium isolated from a pond in McMurdo Dry Valley, Antarctica. Int. J. Syst. Evol. Microbiol. 50, 1533-1561.

${ }^{18}$ Chen, Y.-G., Tang, S.-K., Zhang, Y.-Q., Li, Z.-Y., Yi, L-B., Wang, Y.-X., et al. (2009). Arthrobacter halodurans sp. nov., a new halotolerant bacterium isolated from sea water. Antonie Van Leeuwenhoek 96, 63-70.

${ }^{19}$ Kusano, K., Yamada, H., Niwa, M., and Yamasoto, K. (1997). Propionibacterium cyclohexanicum sp. nov., a new acid tolerant $\omega$ cyclohexyl fatty acid-containing Propionibacterium isolated from spoiled orange juice. Int. J. Syst. Evol. Microbiol. 47, 825-831.

${ }^{20}$ Kleinsteuber, S., Riis, V., Fetzer, I., Harms, H., and Müller, S. (2006). Population dynamics within a microbial consortium during growth on diesel fuel in saline environments. Appl. Environ. Microbiol. 72, 3531-3542.
${ }^{21}$ Kalmbach, S., Manz, W., Wecke, J., and Szewzyk, U. (1999). Aquabacterium gen. nov., with description of Aquabacterium citratiphilum sp. nov., Aquabacterium parvum sp. nov. and Aquabacterium commune sp. nov., three in situ dominant bacterial species from the Berlin drinking water system. Int. J. Syst. Evol. Microbiol. 49, 769-777.

${ }^{22}$ Lin, M.-C., Jiang, S.-R., Chou, J.-H., Arun, A. B., Young, C.C., and Chen, W.-M. (2009). Aquabacterium fontiphilum sp. nov., isolated from spring water. Int. J. Syst. Evol. Microbiol. 59, 681-685.

${ }^{23}$ Chen, W.-M., Cho, N.-T., Yang, S.H., Arun, A. B., Young, C.-C., and Sheu, S.-Y. (2012). Azuabacterium limnoticum sp. nov., isolated from a freshwater spring. Int. J. Syst. Evol. Microbiol. 62, 698-704.

${ }^{24}$ Roder, A., Hoffman, E., Hagemann, M., and Berg, G. (2005). Synthesis of the compatible solutes glucosylglycerol and trehalose by saltstressed cells of Stenotrophomonas strains. FEMS Microbiol. Lett. 243 , 219-226.

${ }^{25}$ Jayasinghearachichi, H. S., Sarma, P. M., Singh, S., Aginihotori, A., Mandal, A. K., and Lal, B. (2009). Fermentative hydrogen production by two novel strains of Enterobacter aerogenes HGN-2 and HT 34 isolated from sea buried crude oil pipelines. Int. J. Hydrogen Energy 34, 7197-7207.

${ }^{26}$ Mantelin, S., Fischer-Le Saux, M., Zakhia, F., Béna, G., Bonneau, S., Jeder, H., et al. (2006) Emended description of the genus Phyllobacterium and description of four novel species associated with plant roots: Phyllobacterium bourgognense sp. nov., Phyllobacterium ifriqiyense sp. nov., Phyllobacterium leguminum sp. nov. and Phyllobacterium brassicacearum sp. nov. Int. J. Syst. Evol. Microbiol. 56, 827-839.

${ }^{27}$ Chen, Y.-G., Cui, X.-L., Wang, Y.-X., Zhang, Y.-Q., Li, Q.-Y., Liu, Z.X., et al. (2009). Salinicoccus albus sp. nov., a halophilic bacterium from a salt mine. Int. J. Syst. Evol. Microbiol. 59, 847-879.

${ }^{28}$ Flint, S. H., Ward, L. J. H., and Brooks, J. D. (1999). Streptococcus waius sp. nov., a thermophilic streptococcus from a biofilm. Int. J. Syst. Evol. Microbiol. 49, 759-767.

${ }^{29}$ Mundt, J. O. (1982). The Ecology of Streptococci. Microb. Ecol. 8, 355-369.

${ }^{30}$ Tominaga, T., An, S.-Y., Oyaizu, H., and Yokota, A. (2009). Sporosarcina luteola sp. nov. isolated from soy sauce production equipment in Japan. J. Gen. Appl. Micribiol. 55, 217-223.

${ }^{31}$ Yoon, J.-H., Lee, K.-C., Weiss, N., Kho, Y. H., Kang, K. H., and Park, Y.-H. (2001). Sporosarcina aquamarina sp. nov., a bacterium isolated from seawater in Korea, and transfer of Bacillus globisporus (Larkin and Stokes, 1967), Bacillus psychrophilus (Nakamura, 1984) and Bacillus pasteurii (Chester, 1898) to the genus Sporosarcina as Sporosarcina globispora comb. nov. and Sporosarcina pasteurii comb. nov., and emended description of the genus Sporosarcina. Int. J. Syst. Evol. Microbiol. 51, 1079-1086.

${ }^{32}$ Kwon, S.-W., Kim, B.-Y., Song, J., Weon, H.-Y., Schumann, P., Tindall, B. J., et al. (2007). Sporosarcina koreensis sp. nov. and Sporosarcina soli sp. nov., isolated from soil in Korea. Int. J. Syst. Evol. Microbiol. 57, 1694-1698.

${ }^{33}$ An, L. Z., Chan, Y., Xiang, S.R., Shang, T.-C., and Tian L.D. (2010). Differences in community composisition of bacteria in four glaciers in western China. Biogeosciences 7, 1937-1952.

${ }^{34}$ Claus, D., Fahmy, F., Rolf, H. J., and Tosunoglu, N. (1983). Sporosarcina halophila sp. nov., an obligate, slightly halophilic bacterium from salt marsh soils. Syst. Appl. Microbiol. 4, 496-506.

${ }^{35}$ Yoon, J.-H., Kim, I.-G., and Oh, T.-K. (2007). Acinetobacter marinus sp. nov. and Acinetobacter seohaensis sp. nov., isolated from seawater of the Yellow Sea in Korea. J. Micrbiol. Biotechnol. 17, 1743-1750.

${ }^{36}$ Onishi, H., and Hidaka, O. (1978). Purification and properties of amylase produced by a moderately halophilic Acinetobacter sp. Can. J. Microbiol. 24, 1017-1023.

${ }^{37}$ Zhao, Z., and Wong, J. (2009). Biosurfactants from Acinetobacter calcoaceticus BU03 enhance the solubility and biodegradation of phenanthrene. Environ. Technol. 30, 291-299.

${ }^{38}$ Sutrisno, A., Ueda, M., Abe, Y., Nakazawa, M., and Miyatake, K. (2004). A chitinase with high activity toward $N$-acetylated chitosan from a new, moderately thermophilic, chitin-degrading bacterium, Ralstonia sp. A471. Appl. Microbiol. Biotechnol. 63, 398-406.

${ }^{39}$ Lee, S. D. (2007). Marmoricola aequoreus sp. nov., a novel actinobacterium isolated from marine sediment. Int. J. Syst. Evol. Microbiol. 57, 1391-1395. 
${ }^{40}$ Gontang, E. A., Fenical, W., and Jensen, P. R. (2007). Phylogenetic diversity of gram-positive bacteria cultured from marine sediments. Appl. Environ. Microbiol. 73, 3272-3282.

${ }^{41}$ Ben-Dov, E., Yosef, D. Z. B., Pavlov, V., and Kushmaro, A. (2009). Corynebacterium maris sp. nov., a marine bacterium isolated from the mucous of the coral Fungia granulosa. Int. J. Syst. Evol. Microbiol. 59, 2458-2463.

${ }^{42}$ Loganthan, P., and Nair, S. (2004). Swaminathania salitolerans gen. nov., sp. nov., a salt-tolerant, nitrogen fixing and phosphatesolubilizing bacterium from wild rice (Porteresia coarctata Tateoka). Int. J. Syst. Evol. Microbiol. 54, 1185-1190.

${ }^{43} \mathrm{Lu}, \quad$ S.-F., Lee, F.-L., and Chen, H.-K. (1999). A thermotolerant and high acetic acid-producing bacterium Acetobacter sp. I14-2. J. Appl. Microbiol. 86, 55-62.

${ }^{44}$ Felske, A., Wolterink, A., Van Lis, R., and Akkermans, A. D. L. (1998). Phylogeny of the main bacterial 16S rRNA sequences in Drentse A grassland soils (The Netherlands). Appl. Environ. Microbiol. 64, 871-879.

${ }^{45}$ Jangid, K., Williams, M. A., Franzleubbers, A. J., Schmidt, T. M., Coleman, D. C., and Whitman, W. B. (2011). Land-use history has a stronger impact on soil microbial community composition than aboveground vegetation and soil properties. Soil Biol. Biochem. 43, 2184-2193.

${ }^{46}$ Hunger, S., Schmidt, O., Hilgarth, M., Horn, M. A., Kolb, S., Conrad, R., et al. (2011). Competing formate- and carbon dioxideutilizing prokaryotes in an anoxic methane emitting fen soil. Appl. Environ. Microbiol. 77, 3773-3785.

${ }^{47}$ Yergeau, E., Newsham, K. K., Pearce, D. A., and Kowalchuk, G. A. (2007). Patterns of bacterial diversity across a range of Antarctic terrestrial habitats. Environ. Microbiol. 9, 2670-2682.

${ }^{48}$ Yoon, J.-H., Lee, K.-C., Weiss, N., Kang, K. H., and Park, Y.-H. (2003). Jeotgalicoccus halotolerans gen. nov., sp. nov. and Jeotgalicoccus psychrophilus sp. nov., isolated from the traditional Korean fermented seafood jeotgal. Int. J. Syst. Evol. Microbiol. 53, 595-602.

${ }^{49}$ Guo, X.-Q., Li, R., Zheng, L.-Q., Lin, D.-Q., Sun, J.-Q., Li, S.-P., et al. (2010). Jeotgalicoccus huakuii sp. nov., a halotolerant bacterium isolated from seaside soil. Int. J. Syst. Evol. Microbiol. 60, 1307-1310.

${ }^{50}$ Hoyles, L., Collins, M. D., Foster, G., Falsen, E., and Schumann, P. (2004). Jeotgalicoccus pinnipedalis sp. nov., from a southern elephant seal (Mirounga leonina). Int. J. Syst. Evol. Microbiol. 54, 745-748.

${ }^{51}$ Liu, Z. X., Chen, J., Tang, S. K., Zhang, Y. Q., He, J. W., Chen, Q. H., et al. (2011). Jeotgalicoccus nanhaiensis sp. nov., isolated from intertidal sediment, and emended decription of the genus Jeotgalicoccus. Int. J. Syst. Evol. Microbiol. 61, 2029-2034.

${ }^{52}$ Martin, E., Klug, K., Frischmann, A., Busse, H. J., Kämpfer, P., and Jäckel, U. (2011). Jeotgalicoccus coquina sp. nov. and Jeotgalicoccus aerolatus sp. nov., isolated from poultry houses. Int. J. Syst. Evol. Microbiol. 61, 237-241.

${ }^{53}$ Shi, W., Takano, T., and Lui, S. (2012). Isolation and characterization of novel bacterial taxa from extreme alkali-saline soil. World J. Microbiol. Biotechnol. 28, 2147-2157.

${ }^{54}$ Lee, E. M., Jeon, C. O., Choi, I., Chang, K.-S., and Kim, C.-J. (2005). Silanimonas lenta gen. nov., sp. nov., a slightly thermophilic and alkaliphilic gammaproteobacterium islated from a hot spring. Int. J. Syst. Evol. Microbiol. 55, 385-389.

${ }^{55}$ Manucharova, N. A., Vlasenko, A. N., Tourova, T. P., Panteleeva, A. N., Stepanov, A. L., and Zenova, G. M. (2008). Thermophilic chitinolytic microorganisms of brown semidesert soil. Microbiology 77, 610-614.

${ }^{56}$ Perfumo, A., Banat, I. M., Canganella, F., and Marchant, R. (2006). Rhamnolipid production by a novel thermophilic hydrocarbondegrading Pseudomonas aeruginosa AP02-1. Appl. Microbial Cell Physiol. 72, 132-138.

${ }^{57}$ Magic-Knezev, A., Wullings, B., and Van der Kooij, D. (2009). Polaromonas and Hydrogenophaga species are predominant bacteria cultured from granular activated carbon filters in water treatment. J. Appl. Microbiol. 107, 1457-1467.

${ }^{58}$ Reddy, P. V. V., Rao, S. S. S. N., Pratibha, M. S., Sailaja, B., Kavya, B., Manorama, R. R., et al. (2009). Bacterial diversity and bioprospecting for cold-active enzymes from culturable bacteria associated with sediment from a melt water stream of Midtre Lovenbreen glacier, an Arctic glacier. Res. Microbiol. 160, 538-546.

${ }^{59}$ Oren, A. (1983). Clostridium lortetii sp. nov., a halophilic obligatory anaerobic bacterium producing endospores with attached gas vacuoles. Arch. Microbiol. 136, 42-48.

${ }^{60}$ Fendrich, C., Hippe, H., and Gottschalk, G. (1990). Clostridium halophilim sp. nov. and C. litorale sp. nov., an obligate halophilic and a marine species degrading betaine in the Strickland reaction. Arch. Microbiol. 154, 127-132.

${ }^{61}$ Brisbarre, N., Fardeau, M.-L., Cueff, V., Cayol, J.-L., Barbier, G., Cilia, V., et al. (2003). Clostridium caminithermale sp. nov., a slightly halophilic and moderately thermophilic bacterium isolated from an Atlantic deep-sea hydrothermal chimney. Int. J. Syst. Evol. Microbiol. 53, 1043-1049.

${ }^{62}$ Tanner, R. S., Miller, L. M., and Yang, D. (1993). Clostridium ljungdahlii sp. nov., an acetogenic species in Clostridial rRNA homology Group I. Int. J. Syst. Evol. Microbiol. 43, 232-236.

${ }^{63}$ Patel, B. K. C., Monk, C., Littleworth, H., Morgan, H. W., and Daniel, R. M. (1987). Clostridium fervidus sp. nov., a new chemoorganotrophic acetogenic thermophile. Int. J. Syst. Evol. Microbiol. 37, 123-126.

${ }^{64}$ Johnson, E. A., Madia, A., and Demain, A. L. (1981). Chemically defined minimal medium for growth of the anaerobic cellulolytic thermophile Clostridium termocellum. Appl. Environ. Microbiol. 41, 1060-1062.

${ }^{65}$ Shewan, J. M., and McMeekin, T. A. (1983). Taxonomy (and ecology) of Flavobacterium and related genera. Ann. Rev. Microbiol. 37, 233-252.
${ }^{66}$ Plakunov, V. K., Zhurina, M. V., and Belyaev, S. S. (2008). Resistance of the oil-oxidizing microorganism Dietzia sp. to hyperosmotic shock in reconstituted biofilms. Microbiology 77, 515-522.

${ }^{67}$ Vankata, R. V., Sasikala, C., Takaichi, S., and Ramana, C. V. (2010). Roseomonas aestuarii sp. nov., a bacteriochlorophyll- $a$ containing alphaproteobacterium isolated from an esturarine habitat in India. Syst. Appl. Microbiol. 33, 198-203.

${ }^{68}$ Kolari, M., Nuutinen, J., Rainey, F. A., and Salkinoja-Salonen, M. S. (2003). Colored moderately thermophilic bacteria in paper machine biofilms. J. Ind. Microbiol. Biotechnol. 30, 225-238.

${ }^{69}$ Kim, M. S., Baik, K. S., Park, S. C., Rhee, M. S., Oh, H.-M., and Seong, C. N. (2009). Roseomonas frigidaquae sp. nov., isolated from a water cooling system. Int. J. Syst. Evol. Microbiol. 59, 1630-1634.

${ }^{70}$ Kämpfer, P., Falsen, E., Lodders, N., and Schumann, P. (2010). Sporosarcina contaminans sp. nov. and Sporosarcina thermotolerans sp. nov., two endospore-forming species. Int. J. Syst. Evol. Microbiol. 60, 1353-1357.

${ }^{71}$ Yamamura, H., Lisdiyanti, P., Ridwan, R., Ratnakomola, S., Sarawati, R., Lestari, Y., et al. (2010). Dietzia timorensis sp. nov., isolated from soil. Int. J. Syst. Evol. Microbiol. 60, 451-454.

${ }^{72}$ Marchandin, H., Teyssier, C., Simeon De Buochberg, M., Jean-Pierre, H., Carriere, C., and Jumas-Bilak, E. (2003). Intra-chromosomal heterogeneity between the four 16S rRNA gene copies in the genus Veillonella: implications for phylogeny and taxonomy. Microbiology 149, 1493-1501.

${ }^{73}$ Wang, Q., Garrity, G. M., Tiedje, J. M., and Cole, J. R. (2007). Naïve Bayesian classifier for rapid assignment of rRNA sequences into the new bacterial taxonomy. Appl. Environ. Microbiol. 73, 5261-5267.

${ }^{74}$ Caporaso, J. G., Kuczynski, J., Stombaugh, J., Bittinger, K., Bushman, F. D., Costello, E. K., et al. (2010). QIIME allows analysis of high-throughput community sequence data. Nat. Methods 7, 335-336. 